\title{
Volume transmission of beta-endorphin via the cerebrospinal fluid; a review
}

\author{
Jan G Veening ${ }^{1,2^{*}}$, Peter $O$ Gerrits $^{3}$ and Henk P Barendregt ${ }^{4}$
}

\begin{abstract}
There is increasing evidence that non-synaptic communication by volume transmission in the flowing CSF plays an important role in neural mechanisms, especially for extending the duration of behavioral effects. In the present review, we explore the mechanisms involved in the behavioral and physiological effects of $\beta$-endorphin ( $\beta$-END), especially those involving the cerebrospinal fluid (CSF), as a message transport system to reach distant brain areas. The major source of $\beta$-END are the pro-opio-melano-cortin (POMC) neurons, located in the arcuate hypothalamic nucleus (ARH), bordering the $3^{\text {rd }}$ ventricle. In addition, numerous varicose $\beta$-END-immunoreactive fibers are situated close to the ventricular surfaces. In the present paper we surveyed the evidence that volume transmission via the CSF can be considered as an option for messages to reach remote brain areas. Some of the points discussed in the present review are: release mechanisms of $\beta-E N D$, independence of peripheral versus central levels, central $\beta$-END migration over considerable distances, behavioral effects of $\beta$-END depend on location of ventricular administration, and abundance of mu and delta opioid receptors in the periventricular regions of the brain.
\end{abstract}

Keywords: $\beta$-endorphin, Pro-opio-melanocortin, Cerebrospinal fluid, Volume transmission, Arcuate nucleus of the hypothalamus, Behavior

\section{Introduction}

There is increasing evidence that non-synaptic communication by volume transmission in the flowing CSF plays an important role in neural mechanisms, especially for extending the duration of behavioral effects $[1-4]$. Beta-Endorphin ( $\beta$-END) is a neuropeptide, produced by pro-opio-melanocortin (POMC) neurons as well as by pituitary cells mainly located in the intermediate lobe $[5,6]$, by cleavage from a larger precursor molecule, beta-lipotropin. $\beta$-END is its $\mathrm{C}$-fragment (containing the amino acids 61-91) and was characterized by Guillemin et al, in 1977 [7,8], in combination with its sister peptides, $\alpha$-melanocyte-stimulating hormone $(\alpha-\mathrm{MSH})$, adrenocorticotropic hormone, $(\mathrm{ACTH})$ and other substances [9-13]. The molecular weight of $\beta$-END is $3465 \mathrm{~g} / \mathrm{mol}$.

The behavioral effects of $\beta$-END were soon recognized and vary from prolonged muscular rigidity [14] to

\footnotetext{
* Correspondence: j.veening@anat.umcn.nl

'Department of Anatomy (109), University Medical Center St. Radboud, PO Box 9101, 6500, HB, Nijmegen, the Netherlands

${ }^{2}$ Department of Psychopharmacology, UIPS, University of Utrecht, Utrecht, the Netherlands

Full list of author information is available at the end of the article
}

general arousal [15]. More specifically, $\beta$-END was shown to play a role in several kinds of behavior, like feeding [16-18], sexual behavior [19,20], learning processes $[21,22]$, reward $[23,24]$, pain-regulating mechanisms [25-31], as well as in a variety of physiological functions such as cardiovascular regulation [32,33] and stress responses [12,34-37].

Interestingly, $\beta$-END is produced in the pituitary for release into the peripheral systemic circulation, and by hypothalamic POMC neurons for release inside the central nervous system (CNS). Since it has been observed that peripheral administration of $\beta$-END does not necessarily induce the same effects as intracerebroventricular (icv) administration, this suggests the existence of two functionally different $\beta$-END systems, one for the central effects and one for the peripheral effects. The present review explores the existence of a special central and brain-directed $\beta$-END system and the possibility that the cerebrospinal fluid (CSF) plays a special role in the propagation of these brain-directed $\beta$-END messages.

The evidence discussed in the present review has led to the conclusion that CSF-levels of $\beta$-END are not a reflection of the peripheral levels, but are controlled and 
regulated by separate inputs and by specific mechanisms that are functionally separate from the pituitary release mechanisms involved in the plasma levels. This conclusion does not necessarily indicate that central CSF and peripheral plasma levels of $\beta$-END are totally unrelated. Peripheral $\beta$-END may be able to access the CNS from the periphery via the circumventricular organs (CVO's) lacking in a blood-brain barrier (BBB), and the choroid plexus $[38,39]$. In addition, the spinal cord seems to be accessible for entrance of blood born proteins [40] and for reentrance of proteins circulating in the surrounding arachnoid space [41-43]. In the other direction, a saturable transporter mechanism, P-glycoprotein, from brain to blood makes it possible that CSF peptides like $\beta$-END can gain access to peripheral systems at the brain capillaries [44-46]. These and other efflux mechanisms most probably serve a modulatory purpose to integrate central/behavioral and peripheral responses.

The flowing CSF serves as a medium to transport neuropeptides or other substances to distant receptive brain areas. This type of transport has been described as longdistance volume transmission (VT) [1-3,39,47-56]. For a few neuropeptides, the evidence favoring such a message function for the CSF has been reviewed in more detail: for vasopressin, corticotropin releasing hormone (CRH) $[48,49]$, and for oxytocin (OT) [4]. For other substances, like melatonin, gonadotropin-releasing hormone as well as for factors influencing food intake, the evidence is convincing that substances, released into the ventricular system at a specific site, exert their effects at a different brain location, arriving there by moving with the flow of the CSF [57-66].

On the basis of the evidence presented here, we propose the following: There are two functionally different systems for the release of $\beta$-END, one for the peripheral effects via the systemic circulation and one directed to the central nervous system. The latter system uses synaptic communication and additional volume transport mechanisms provided by the flowing CSF. It is on the second part of this hypothesis that our present paper is focused.

\section{Sources of $\boldsymbol{\beta}$-END \\ POMC neurons in the hypothalamic arcuate nucleus (ARH)}

Numerous immunocytochemical as well as in situ hybridization studies have confirmed the existence of a main population of $\beta$-END-immunoreactive (IR) neurons in the mediobasal hypothalamic region, most of them located in the arcuate hypothalamic nucleus (ARH) [67-73] (Figure 1). These neurons have been described as pro-opio-melanocortin (POMC) neurons because in these neurons a large precursor molecule (POMC) is cleaved into smaller peptides, like ACTH, $\alpha-$

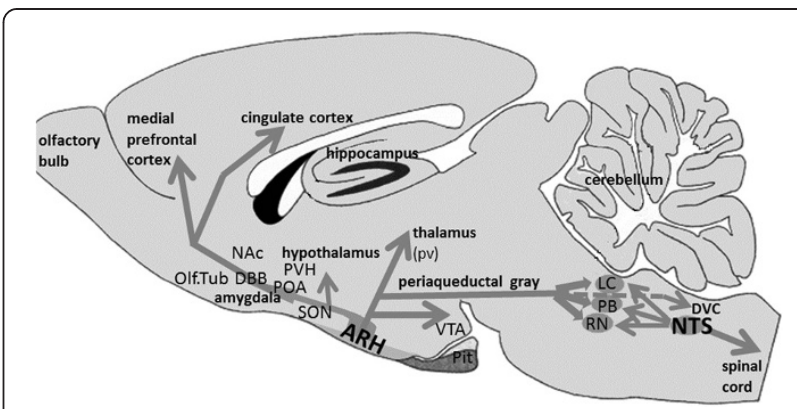

Figure 1 Diagram showing the opiocortin projections from the arcuate nucleus of the hypothalamus. The arcuate nucleus (ARH) contains most $\beta$-END cell bodies and is located in the mediobasal hypothalamus, at both sides of the $3^{\text {rd }}$ ventricle (not shown). Extensive opiocortin projections arise from the ARH and extend in rostral, cortical, hypothalamic and caudal brainstem directions. The most caudal projections extend into the dorsal vagal complex (DVC), comprising the area postrema, the dorsal vagal nucleus and the nucleus of the solitary tract (NTS). Limbic regions predominate as target areas for the ARH projections. In the caudal brainstem, in the NTS itself, another group of $\beta$-END cells has been detected. Their opiocortin fibers project mainly to brainstem areas as well as down the spinal cord. A number of brainstem areas, involved in numerous autonomic functions, receive a double innervation from both the $\mathrm{ARH}$ and the NTS: locus coeruleus (LC), the parabrachial region (PB) and several raphe nuclei (RN). Abbreviations: NAc: nucleus accumbens; Olf. Tub: olfactory tubercle; DBB: diagonal band nuclei; POA: preoptic area; PVH: paraventricular hypothalamic nucleus; SON: supraoptic hypothalamic nucleus; pv: periventricular thalamus; Pit: pituitary; VTA: ventral tegmental area.

MSH and $\beta$-END $[11,71]$. At the electron microscope level, $\beta$-END IR processes penetrate the ependymal layer of the basal hypothalamic ventricular wall as well as the pia mater overlying the ventral surface of the hypothalamus [73]. The axons traverse the sub-ependymal layers and show many varicosities, local swellings containing numerous vesicles but without synaptic specializations, suggesting local non-synaptic release mechanisms [11,68,73-76]. Also, in Xenopus, $\beta$-END neurons have been described as contacting the CSF directly $[77,78]$. These contacts make it possible for the hypothalamic $\beta$ END cells to release their contents into either the CSF of the $3^{\text {rd }}$ ventricle or of the subarachnoid space [79], bordering the ARH ventrally. Interestingly, many POMC neurons also participate in an intrinsic local network resulting in many POMC-POMC synapses inside the ARH [80]. Such contacts may synchronize the activities of the POMC neurons to integrate or coordinate as a functional unit, and this mechanism may regulate the amount of $\beta$-END released into the CSF.

The process of cleaving POMC molecules, followed by additional processing during axonal transport (see below), controlled release and extrinsically controlled levels of receptors (see below), provides the POMC system with a high degree of plasticity. We mention a few aspects: Firstly, while ACTH, $\beta$-END and $\alpha-\mathrm{MSH}$ are 
fully co-localized in the ARH POMC neurons [69,70,72], their cellular concentrations are rather different. Secondly, ACTH and $\beta$-END are present in the same secretion granules [81] in about equimolar quantities, but the amount of $\alpha-\mathrm{MSH}$ is at least 4 times higher in the cell bodies and up to 15 times higher in some terminal fields [70], suggesting that further processing of these neuropeptides occurs during axonal transport [70,82]. Therefore, it is improbable that the POMC derivatives will be secreted in a fixed balance over all trajectories or terminal fields [83]. In addition, Swanson et al [84-86] have shown that in paraventricular hypothalamic neurons, the balance between co-localized neuropeptides is under regulatory control, and can be disturbed by external factors like manipulation of the pituitaryadrenal axis or gonadectomy $[84,86-88]$. Such plastic fluctuations may lead to considerable variations in connectivity and to serious disturbances in the effects of activity in specific neuronal networks. Since similar changes seem to occur in the $\beta$-END projections to the supraoptic nucleus [89], these mechanisms appear to work in the POMC system also.

The extrinsic projections of the hypothalamic POMC neurons, also known as opiocortin projections, have been mapped extensively $[68,76,90-96]$. Their trajectories and destinations extend from rostral telencephalic regions, like the olfactory tubercle and diagonal band nuclei, to caudal brainstem areas like the ambiguous and lateral reticular nuclei $[11,67,71]$.

There are a number of aspects of the POMC circuitry that deserve special attention. There is a prevalence of POMC projections in brain areas such as the amygdala (central and medial nuclei), hypothalamus, periventricular thalamic nuclei and the periaqueductal gray (PAG). In the hypothalamus the densest innervations are provided to the parvocvellular, paraventricular, preoptic, periventricular and arcuate nuclei, which are all involved in anterior pituitary functions, via the median eminence [70]. The relationship between the paraventricular and supraoptic hypothalamic nuclei, including their magnocellular parts, has been studied in detail $[89,94,97-101]$ and indicate possible modulatory effects of ACTH or $\beta$-END on the peripheral release of vasopressin or oxytocin (OT). A remarkable co-distribution has been recognized between opiocortin fibers and the corticotrophin-releasing factor (CRF)-immunoreactive fibers $[67,102]$, suggesting a specific role of $\beta$-END on the effects of activation of the hypothalamus-pituitary-adrenal (HPA) axis, involving stress. In addition, the catecholaminergic cells, like noradrenergic neurons in the locus coeruleus as well as serotonergic neurons in the pontine raphe nuclei $[67,93]$ receive a dense POMC innervation which suggests a regulatory involvement of $\beta$-END in a wide variety of brain functions. The more so as these brainstem regions receive additional opiocortin fibers from the neurons located in the lower brainstem (see below).

Studies combining retrograde tracers with POMC staining techniques have shown that subpopulations of the POMC neurons project to different destinations [103]. The $\beta$-END innervation of the ependymal and subependymal layers surrounding the ventricular system is extremely dense at some locations but varies considerably $[67,68,70,73-76,93,95,104]$. Despite the common origin of the POMC-derived neuropeptides, the relative densities of the ACTH, $\beta$-END and $\alpha$-MSH fibers along the ventricular walls also varies considerably [70].

\section{POMC neurons in the caudal brainstem}

In 1983 an additional group of opiocortin neurons was described in the caudal brainstem, within the commissural division of the nucleus tractus solitarius (NTS) $[67,105]$. These neurons project rostrally towards several pontine and medullary regions that also receive projections from the ARH. Apparently, autonomic brainstem regions like the parabrachial nucleus and locus coeruleus are provided with a double opiocortin innervation originating from both the arcuate nucleus and the caudal brainstem [106]. Other projections from this caudal group descend into the spinal cord, via the (dorso-)lateral funiculus to terminate around the central canal, and may be involved in the modulation of pain transmission [107].

\section{Pituitary: the source for peripheral release}

In addition to the POMC neurons in the brain, the pituitary contains large numbers of POMC-producing cells. These cells are located in the intermediate as well as in the anterior lobe. Interestingly, however, the processing of the large POMC molecule seems to vary in different parts of the pituitary. In the anterior pituitary cells, ACTH is one of the main products of the POMC fragmentation, while in the intermediate lobe $\beta$-END and $\alpha-\mathrm{MSH}$ predominate as the main fragments of POMC processing $[11,13,36,108-110]$. The paucity of vessels in the intermediate lobe $[111,112]$ raises questions about the route used after cellular release, the more so as the human pituitary does not have a distinct pars intermedia, which is present in the whale, elephant and several other mammals [113]. Accordingly, only very low concentrations of $\alpha-\mathrm{MSH}$ can be detected in the adult human pituitary gland $[113,114]$. These questions, related to the specific release mechanisms of the pituitary, are, however, beyond the scope of our present review.

In summary, there are three sources of POMC and its derivatives including $\beta$-END: the ARH, NTS and pituitary. The first two are directed towards the CNS 
including the spinal cord, the last one towards the systemic circulation and peripheral organs.

\section{Central and peripheral $\beta$-END are regulated differentially \\ Peripheral changes in $\beta$-END only minimally affect CSF $\beta$-END}

Early experiments showed that $\beta$-END in brain changed very little, or not at all, after hypophysectomy, while the peripheral concentration decreased dramatically and it was concluded that brain and peripheral $\beta$-END were regulated independently $[8,110,115]$. To study the differential regulatory mechanisms in more detail, the relative concentrations of $\beta$-END in CSF and plasma were determined. The CSF/plasma ratio ranged from 1.5 to 3 in rodents, [115-118] with an occasional exception [119], and up to 10 in humans [12,113,115-128], also with an occasional exception [129]. These variations appeared to be due to the diversity of methods and experimental conditions involving stress, pain-related manipulations, and infections [111,113,116-118,120,129-133]. Another complicating factor is that $\beta$-END levels show diurnal fluctuations in plasma as well as in the CSF $[134,135]$. The conclusion is that CSF $\beta$-END concentration mostly exceeds peripheral $\beta$-END, which excludes the possibility that central levels are a passive reflection of peripheral levels.

The functional correlation between CSF- and peripheral $\beta$-END is clear. With only one exception [136], all papers reporting a wide variety of experimental conditions, agree on the existence of complete dissociation between blood and CSF levels of $\beta$-END and on specific and different central versus peripheral regulatory mechanisms [116,120-122,128,129,137-140]. All studies since 1990 have consistently drawn the same conclusion: an intact BBB prevents the free exchange of $\beta$-END between plasma and CSF. Half-life values of $\beta$-END vary from 2 to $10 \mathrm{~min}$ in the peripheral circulation of rat and rabbit and between 20 and $50 \mathrm{~min}$ in the human circulation $[115,141,142]$, while in the CNS, degradation of $\beta$-END hardly occurs at all $[141,142]$. The age-related changes throughout human life are also completely different: the peripheral levels show a parabolic peak at the age of about 50 years, while the CSF shows a steady decrease over the successive decades of life, down to less than $25 \%$ of peak at the age of $70+$ [122].

Despite the general conclusion about separate central and peripheral control mechanisms, we have to keep in mind that the plasma and CSF compartments of $\beta$-END are not completely independent. Early experiments in the rabbit [115] already showed a steady but slow increase in CSF concentration after a single intravenous bolus injection of a radiolabeled marker. Starting after about 30 seconds, the radioactivity levels in the CSF increased up to
$20-25 \%$ of the periphery after $60-90$ minutes [115]. Apparently, peripheral $\beta$-END has some limited access to the CSF, but the delay is considerable. De Kloet et al [111] have discussed these possible pituitary-brain opiocortin transport mechanisms, consisting of vascular backflow via the terminal branches of the subependymal plexus [143], or backflow via the CSF and the pericapillary spaces of the median eminence [111] or uptake and retrograde axonal flow from the pericapillary spaces of the portal vessels [144]. In addition, membrane transporters of the organic anion-transporting polypeptide (Oatp) family may play a role in the transport of opioid peptides across the BBB and blood-CSF-barrier of the mammalian brain [145]. Such mechanisms may serve some long-term modulatory effect but are far too slow to affect changes in behavioral states, let alone the immediate physiological reactions to a painful stimulus.

\section{CSF $\beta$-END can be manipulated without affecting the peripheral levels}

The strongest evidence that there is a separate central mechanism for $\beta$-END comes from the following experimental manipulations that induced elevated CSF levels without affecting peripheral concentration: electrical and chemical stimulation $(10 \mathrm{~Hz})$ of the ARH [146-148]; obesity [126] and ischemic attacks and strokes [125]; electroconvulsive shocks [149] and methadone maintenance schedules [150]; learning processes causing rapid CSF increases [151,152] and low levels of vasopressin affecting the release as well as the clearance of $\beta$-END from the CSF $[116,153,154]$. In these experiments in the rat brain, cisterna magna cannulation was shown to have differential effects on levels of $\beta$-END in plasma and CSF, which lasted for hours or even days [120].

In conclusion, for the purpose of the present review, we assume that the effects of peripheral levels of $\beta$ END on the CSF-levels are too limited and too slow to explain any of the direct brain and behavioral effects of central $\beta$-END. The extracellular pathways involved have been discussed by Banks and may possibly play a role in long-term treatment of Alzheimer's disease or stroke $[155,156]$.

Summarizing, we conclude that the available data suggest that central $\beta$-END effects on the CNS may occur in three successive stages using different time intervals. First, in a matter of milliseconds, $\beta$-END released from terminals and varicosities of the $\beta$-END-IR fibers may have immediate action on the neighboring receptive neuronal elements. Second, $\beta$-END, arriving with the flow of the CSF after seconds or only a few minutes, may influence a larger number of receptive brain areas for a longer period of time, partially sustaining the earlier neuronal release effects. Third, elevated peripheral levels of $\beta$-END slowly penetrate the CSF compartment 
and induce after a delay of $30 \mathrm{~min}$ or more, some increase in CSF concentration. However, these slow effects are perhaps modulatory and do not seem to play a role in the behavioral or pain-suppressing effects of $\beta$-END discussed below.

\section{$\beta$-END in the CSF}

Short- and long-distance volume transmission (VT)

From the earliest reports, it has been recognized that POMC-fibers closely surround the ventricular spaces, traverse the subependymal layers and contain many varicosities. These may release their contents by nonsynaptic release or exocytosis, either into the CSF or into the neighboring extracellular fluid (ECF) where it can influence receptive neurons locally $[4,11,157,158]$. This phenomenon has been denoted volume transmission (VT) $[1-3,50,55,159,160]$. It can work at short as well as long distances, guided by fiber tracts or by the flow of the CSF. Beta-END released from the ARH is in an excellent position to use long-distance VT for sending messages to a variety of brain areas using the caudallydirected flow of CSF (Figure 2). Beta-END was involved from the beginning in the development of the concept of volume transmission including the flow of CSF, as one of the distribution mechanisms [1-3,51,56,160-166]. Long-distance VT via the CSF has been implicated for a number of other neuromessengers: vasopressin and corticotropin-releasing hormone (CRH) $[48,49]$, oxytocin [4], melatonin and gonadotropin-releasing hormone as well as for factors influencing food-intake [57-66].

Strategic location of the ARH: The median eminence of the hypothalamus is open to the portal vessels connecting the hypothalamus to the pituitary, without a BBB-ensheathment, but closed to the CSF. On the other hand, the ARH is open to the CSF in the third ventricle and in the subarachnoid space. Along the dorsolateral and ventromedial borders, the ARC is completely surrounded by relatively impenetrable barriers [79,167]. These barriers consist mainly of tanycyte processes [167172], which impede the diffusion of neuropeptides from the ARH into either the medially-located median eminence or the dorsolaterally-adjoining ventromedial hypothalamic nucleus [79]. This diffusion blockade in medial and lateral directions, combined with the open passage towards the third ventricle and the subarachnoid space $[79,167,168,170,171]$, suggests that an activated group of POMC neurons in the ARH creates high levels of intranuclear POMC products that can only be released into the ventricular CSF (dorsomedial direction) or into the subarachnoid CSF (ventral direction). In addition to behavioral effects, opioid receptors are abundantly expressed in the proliferative zones of the fetal rat brain. They are likely targets for peptides distributed by CSF bulk flow and play a key role in modulating the mitotic activity and growth in neurogenic regions of the CNS [173]. The POMC neurons in the ARH are readily accessible for signals arriving within the CSF, because the flow along the ARH is slow due to the local absence of multiciliated cells [79]. On the other hand, $\beta$-END easily diffuses considerable distances in the brain [163]. The existence of a very long half-life of $\beta$-END in the CNS $[142,174]$ supports the existence of these long-distance effects.

Natural conditions rapidly increase central $\beta$-END levels: There are behavioral conditions under which the $\beta$-END level increases rapidly in the CSF. Many animal and clinical studies have measured CSF and peripheral levels of $\beta$-END but observations were taken at $15 \mathrm{~min}$ utes after the experimental challenge [117,175]. In a limited number of studies, observations did start immediately, providing clear information about the speed of onset of the $\beta$-END reaction and/or effects [176,177]. Learning experiments using passive avoidance induced

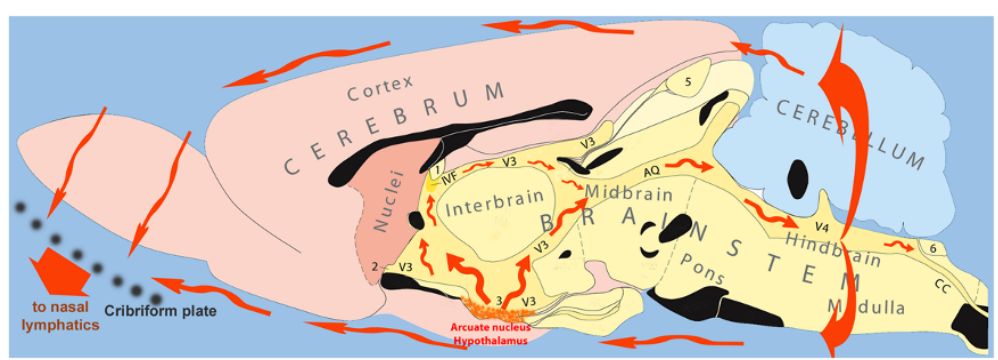

Figure 2 Diagram showing the flow of CSF in the volume transmission of $\boldsymbol{\beta}$-endorphin. The main release site for $\beta$-END is the arcuate nucleus of the hypothalamus. The additional hindbrain site is located just ventral to no 6 . The flow of the CSF (red arrows) traverses the aqueduct (AQ) to penetrate the mesencephalic periaqueductal gray before reaching the $4^{\text {th }}$ ventricle (V4), and along the 'vagal-complex' region. Both regions are important target areas for the flowing $\beta$-END. After leaving the ventricular system, the flowing CSF may affect superficial brain regions in the brainstem, hypothalamus and olfactory regions. A considerable part of the CSF and its contents eventually leaves the cranial cavity along the olfactory nerves penetrating the cribriform plate. The telencephalon is indicated in pink colours. The diencephalon ('interbrain') is coloured yellow, similar to the brainstem structures and the cerebellum is blue. Black structures show the location of fiber systems which cross the midline. Other symbols: numbers 1-6: circumventricular organs; cc: central canal of spinal cord; IVF: interventricular foramen, connecting the lateral and the $3^{\text {rd }}$ ventricles; V3: $3^{\text {rd }}$ ventricle. (The original figure was kindly provided by L.W. Swanson). 
maximal CSF levels within 5 minutes [152,164]. After a variety of behavioral procedures, hypothalamic release of $\beta$-END started within a few minutes [151,178]. The amounts released, 20-40 ng per brain, are 8-10 times higher than the 2-5 ng needed to induce a behavioral effect after icv administration [151,178]. The effective dose after peripheral administration, on the other hand, is about $140 \mathrm{ng} /$ rat [151], which is not inconsistent since only about $20 \%$ of the peripheral $\beta$-END may eventually reach the CSF by two hours after the injection $[115,151]$.

Artificially raised $\beta-E N D$ in the CSF induces rapid effects: Periventricular brain stimulation for pain relief in humans, resulted in an increase in $\beta$-END levels in the third ventricle CSF to a maximal value up to 20 times the basal level, within five minutes [176,177]. After icv administration of $\beta$-END, behavioral effects such as masticatory jaw movements, started within the first minute [179]. These rapid effects illustrate the capacity of the $\beta$ END system to release considerable amounts of the neuropeptide into the CSF, without delay. The following studies suggest that transport via the CSF is the best possible explanation for the observed effects. Chromaffin adrenal medullary cells produce and secrete several potential pain-reducing substances, including opioid peptides [180,181]. Yadid et al. [182] transplanted these cells into the subarachnoid space of the spinal cord of the rat and observed a marked reduction in pain behavior and showed the involvement of the central $\beta$-END mechanisms and the ARH in the observed analgesia, apparently via long-distance VT. In an another interesting study [183], genes were transferred into the meninges surrounding the spinal cord, causing pia mater cells to produce $\beta$-END. Clear analgesic effects were observed in an inflammatory model of persistent pain, apparently induced by $\beta$-END release into the CSF [183].

Uptake of $\beta$-END from the CSF: For our hypothesis concerning long-distance VT, we also need to establish that specific ependymal and other cells, partially remote from the ventricular surface, are able to take up specific substances from the CSF. Such ependymal and neuronal elements are abundantly present throughout the ventricular system, including the lateral and fourth ventricles, and have been located in both forebrain (dentate area of the hippocampus, lateral septum, thalamus and hypothalamus) and a variety of brainstem areas, especially the raphe nuclei [51,53,161,184-186]. Retrograde flow mechanisms take care of the transport of substances like $\beta$-END, from the CSF towards the soma of neurons remote from the ventricles where they may elicit responses leading to changes in gene expression [51].

\section{Dendritic release of $\beta$-END?}

The strategic situation of the POMC system shows striking similarities to that of the oxytocinergic (OT) system, which in mammals has two separate nuclei, the paraventricular hypothalamic nucleus bordering and freely accessing the third ventricle, and the supraoptic hypothalamic nucleus bordering and freely accessing the subarachnoid space, reviewed in [4]. The magnocellular oxytocinergic neurons release major amounts of OT via their dendrites [187-189], by inducing neighboring OT dendrites to join the OT release in the manner of a chain reaction and leading to a thousand fold increase in local concentrations of OT [190-192]. This questions how far dendritic release mechanisms of POMC neurons inside the ARH also play a role in the observed elevations of POMC levels in the nucleus as well as in the CSF. Direct evidence for such a release of $\beta$-END has not yet been obtained. This lack of data may just reflect the fact that the POMC population is more difficult to investigate than that of the OT-neurons, because of their location, density and their smaller size and other cellular characteristics. Although numerous contacts between, and the dense POMC innervation of POMC neurons, suggest that axonal/terminal release is the main mechanism for activating the POMC neurons as a group [92], some experimental findings make it implausible that interneuronal POMC-POMC interactions are purely axonal/terminal. First, it has been shown that dendrites in the ARH with and without spines may extend several hundreds of microns or even more than $1 \mathrm{~mm}$ in a dorsal or rostral direction from the nuclear borders $[172,193]$. Far away from the soma, thin fibers, probably axonal collaterals, arise from these POMC dendrites, suggesting that dendritic and axonal functions are not fully separate spatially or functionally [193]. POMC dendrites extending as far rostrally as the preoptic region were shown to release endocannabinoids to control local GABAergic inhibition [193], while in the opposite direction cannabinoids control the expression of $\beta$-END [194]. As dendrites from POMC-neurons extend and release substances far outside the anatomical border of the $\mathrm{ARH}$ itself, it seems worthwhile to study dendritic release mechanisms and their role in the interneuronal POMC interactions.

\section{Peptide release from POMC neurons: plasticity}

In 1982, O'Donohue and Dorsa [113] mentioned that POMC neurons "secrete at least seven peptides which can be biotransformed to as many as five active peptides after release". As mentioned before (section above), further processing of these neuropeptides may occur during axonal transport $[70,82,83]$. Fluctuations in functional plasticity have been discussed (see above) which may lead to considerable variations in connectivity, including serious disturbances in activity in specific neuronal networks. A similar influence has been described for $\beta$-END projections to the supraoptic nucleus [89]. In this case, 
however, manipulation of the pituitary-adrenal axis did not have much effect on mediobasal hypothalamic ACTH levels [195]. In addition, it has been observed that the amount of POMC, secreted into the CSF was 10-100 times larger than the amount of $\mathrm{ACTH}$ or $\beta$-END $[196,197]$. Energy homeostasis, with leptin playing a crucial role [198-200], caused great variability in the balance between POMC and its derivatives, ACTH or $\alpha-\mathrm{MSH}$, in the $\mathrm{ARH}$, which is richly provided with leptin receptors. Variations in the CSF-levels turned out to be more pronounced than in the ARH brain tissue itself [198]. Apparently, the balance between diverse POMC products is regulated and hormonal signals controlling food intake are involved in this effect. Finally, a mutually balancing mechanism has been proposed between $\beta$-END on the one hand and the melanopeptides (ACTH and $\alpha-\mathrm{MSH}$ ) on the other, in that continuous icv infusion stimulates the development of tolerance as well as increased production of the counterbalancing peptides in the ARH [201,202].

From these data, we conclude that plasticity in the peptide cocktail of the POMC neurons does indeed occur. In addition to tolerance effects, hormonal factors, so far mainly controlling energy homeostasis, may induce changes in the composition of the peptide cocktail which may have serious consequences for the different activation/inhibition patterns in the projection areas of the opiocortin neurons. Interestingly, such plastic changes are even region-specific to some extent, because certain hormonal conditions induced changes in local hypothalamic $\beta$-END levels only, without affecting other hypothalamic nuclei [203]. In addition, and very importantly for the purpose of the present review, the CSF levels of POMC and its derivatives are not a mere reflection of the intracellular neuropeptide balance, but are controlled by specific mechanisms. See Pritchard and White [200] for an extensive review of the cellular mechanisms involved.

\section{Functional subgroups of $\beta$-END neurons}

Interestingly, many POMC neurons participate in a dense local network resulting in POMC-POMC synapses inside parts of the ARH $[67,68,70,72,73,80,90,92,95]$. As suggested by a similar mechanism for oxytocin reviewed by Veening et al [4], such contacts may synchronize the activities of the POMC neurons forming one or more functional units, allowing them "to perform coherently as a robust processing unit" [204], for instance to provide the considerable amounts of POMC needed to elevate the CSF levels.

Anatomically, the population of POMC neurons does not form a single functional unit. As mentioned, there are two groups of neurons, one located in the ARH and other in the NTS. These sources have widely diverging projections: the ARH mainly to mesencephalic, hypothalamic, limbic and forebrain areas, and the NTS mainly to the caudal brainstem and spinal cord $[106,107]$. Overlapping projections from both groups were only observed in a number of brainstem areas, like locus coeruleus and parabrachial nucleus, with a distinctive pattern for both projections in the latter [106].

But even the POMC neurons in and around the ARH do not seem to be a single homogeneous group either anatomically or functionally. Retrograde tracer studies combined with POMC-immunocytochemical staining are relatively scarce but where available they show that only a limited portion of the POMC neurons become labeled after each tracer injection, with several indications for a topographical organization of the origins. Such retrograde double-labeling studies showed that only about $20 \%$ of the POMC neurons project to the preoptic area $[101,103]$. Labeled neurons were bilaterally distributed throughout the rostrocaudal extent of the ARH, with a peak at the middle levels [101], roughly coinciding with subgroup 1 described in [68]. After more dorsal preoptic injections, the pattern of labeled POMCneurons tended to shift to the lateral parts of the ARH [101]. Chronwall [205] observed a similar distribution after preoptic injections, without rostrocaudal differentiation, but ARH neurons projecting into the PAG were observed more dorsolaterally, with only a small percentage of neurons projecting to both brain areas. Yoshida and Taniguchi [96] demonstrated that most of the PAGprojecting neurons were concentrated in the rostral three-fifths of the ARH, about $20 \%$ of them containing $\beta$-END. Sawchenko et al. [94] showed that about 600 basomedial hypothalamic neurons could be stained for ACTH, and about $40 \%$ of them, mostly in the ventral part of the ARH, projected to the paraventricular hypothalamic nucleus. More recently, Douglas et al. [89] found that in the rat, the number of POMC-producing neurons in the ARH increases considerably during pregnancy, especially caudally, whereas the retrogradelylabeled ARH neurons projecting to the supraoptic nucleus, contained about $20 \% \beta$-END. All of these tracer experiments suggest that each of the projections arises from a limited number of $\beta$-END neurons, and additional quantitative experiments are required to elucidate this aspect.

Estrogen receptivity is another factor differentiating between $4-20 \%$ of the $\beta$-END neurons from the majority of the neuronal population [206-208]. These neurons have been observed equally dispersed over the total $\beta$-END population and their number may vary upward or downward by about $50 \%$ after manipulation of estrogen levels $[207,209]$. It was known already that the distribution pattern of $\beta$-END-fibers in the medial part of the medial preoptic nucleus show sexually dimorphic differences 
[210] while castration of photostimulated male hamsters induces $>50 \%$ increase in $\beta$-END levels in the mediobasal hypothalamus [203].

In summary, it is clear that $\beta$-END neurons 'never walk alone', anatomically and functionally, but operate in subgroups distributed over different regions of the ARH. Projections to specific brain regions may arise from different subgroups of $\beta$-END neurons, since there are multiple indications for functional differentiation, e.g. estrogen receptivity, as well as topographical organization in the distribution of the fibers originating from different parts of the ARH. Additional experiments, combining various retrograde tracers with immunological or in situ hybridization techniques, are required to elucidate the functional topographical organization of the mediobasal hypothalamic $\beta$-END neurons in more detail.

\section{Summary and questions}

From the preceding sections we conclude that $\beta$-END can be released into the CSF in sufficient quantities to induce physiological and/or behavioral effects. The $\beta$ END neurons are located in the mediobasal hypothalamus with, on the one hand, interconnections which permit them to function as sub groups and on the other an internal topographical organization, enabling them to send messages to specific targets. Dendritic release from POMC neurons in the ARH probably occurs but its contribution relative to axonal release from varicosities and terminals, remains to be investigated. Production and release of POMC and its derivatives is under control of external factors such as leptin, for energy homeostasis. This implies that differential messages can be released into the CSF and/or neuronal target areas participating in the involved neuronal circuitry. From this summary, it is clear that quite a few questions remain to be answered. What are the input-output relationships among and within the subgroups of POMC neurons? Do all POMC subgroups contribute to the release into the CSF? Which external factors influence the activity and productivity of POMC neurons? Do all POMC neurons show the same sensitivity for factors like leptin or GABA-ergic inhibition via the preoptic region?

While several additional questions can be raised, those mentioned can all be studied by combinations of readily available techniques.

\section{Long-Distance VT effects of $\boldsymbol{\beta}$-END}

\section{Downstream location of $\beta$-END receptive brain areas}

$\beta$-END reacts with at least two types of opioid receptors: mu and delta [211]. The location of these receptors has been determined using a variety of methods, ranging from binding studies to recent mRNA techniques [212228]. The distribution patterns are quite different for the two receptor types and a full discussion would go far beyond the scope of the present review. Furthermore, the distribution patterns vary widely between different species [211,221].

There is a so-called ligand-receptor mismatch, where the distribution of immuno-labeled terminals is different to the distribution of the relevant receptors $[229,230]$. In fact, the occurrence of this $\beta$-END terminal-receptor mismatch was the starting point for the concept of VT as developed by Agnati and Fuxe and coworkers [1$3,50,52-56,159,161,165,166,230]$. Some of the important areas where $\beta$-END has an effect will be mentioned. MacMillan et al [148], studied the destination of $\beta$-END released by low-frequency electrical stimulation of the ARH. They concluded that "the cerebrospinal fluid is an important mechanism of the transport of $\beta$-END" and that in this way " $\beta$-END will affect brain function in a widespread or global manner". The many circumventricular $\beta$-END-receptive areas show considerable differentiation [148]. The periaqueductal gray (PAG) and the vagus complex are among the first brain areas exposed to elevated levels of $\beta$-END released into the CSF. These brain areas are highly receptive and play a prominent role in pain-regulation, sexual behavior and food intake, as discussed below. The distance between these brain areas and release from the ARH is so small that volume transmission may take effect almost immediately.

In the human brain, specific endorphinoreceptive neurons have been described in the deeper layers of the cingulate and frontal cortices, which are densely ensheathed by $\beta$-END terminals [231]. These layers are easily accessible for $\beta$-END in CSF. The analogous areas in the rat brain were shown previously to be highly opioid receptive [212]. In between the many densely-innervated brain areas, it is remarkable that large parts of the brain, like most of the neocortex, striatum and hippocampus, but also a few specific hypothalamic nuclei like the ventromedial hypothalamic nucleus and the mammillary nuclei, are virtually devoid of any opiocortin innervation [211].

Receptor density alone may not be the best indicator for the size of the expected effect, behaviorally or metabolically, because of possible indirect effects. Ableitner and Schulz [179] measured the local cerebral glucose utilization, as a correlate of neuronal activity, after icv administration of $\beta$-END in the rat. The most marked increases were observed in the hippocampal formation despite the lack of opiocortin innervation, especially the ventral components, and in some closely-related limbic areas. Thalamic nuclei and the caudate-putamen complex, harboring high densities of mu and delta receptors, respectively, hardly reacted to the icv-administration.

It has been shown by Herbert and his coworkers [232-235] that the behavioral effects of local $\beta$-END infusion may be very subtle, affecting only some specific behavioral transitions. Such local effects can elucidate the 
specific effects of $\beta$-END but they easily get hidden when focusing only at the general behavioral effects of the neuropeptide. $\beta$-END is known to induce euphoria and to have rewarding and reinforcing properties [236]. Numerous recent reviews have discussed the involvement of mu receptors in the 'liking' and 'wanting' aspects of food reward [237-247]. The functional relationship between the rewarding aspects of sexual behavior and the involvement of opioids are also supported in a series of papers and reviews [15,248-259]. The bidirectional interactions between the opioid systems, including $\beta$-END, and the mesolimbic (and incerto-hypothalamic -dopaminergic systems form neural substrates for the reward effects of eating and sexual behavior and can be considered as crucial components of the mechanisms involved in motivational drives and goal-directed behavior. The motivational effects of numerous neuroactive substances reflect their inhibitory or excitatory action on this dopaminergic reward system, extending between the ventral tegmental area and the nucleus accumbens. It has been stated that "The (induction of a) reward state in males and females is mediated by opioids and the medial preoptic area of the anterior hypothalamus is a crucial site for sexual reward" [252]. In addition, $\beta$-END also plays a role in addiction because of its mutual modulatory relationships with the mesolimbic dopaminergic system [260-265].

Is 'addressing' of $\beta$-END used for regional specific effects? The findings discussed in the preceding sections raise interesting possibilities. If POMC neurons function in separate groups, then messages may be released into specific areas of the ventricular system and affect particular CNS sites responsible for physiological/behavioral reactions. There is evidence to support this. Experiments show that when a specific messenger is released into the ventricular system, the location plays an important role in the resulting effects. For example, administration of 5 -HT into the lateral but not the $3^{\text {rd }}$ ventricle stimulated female sexual behavior in rats [266] and oxytocin administered into the lateral ventricle but not into the 3rd ventricle, suppressed lordosis [267]. On the other hand, $\beta$-END administered into the lateral ventricle facilitated lordosis but inhibition occurred after $3^{\text {rd }}$ ventricular administration [268]. Similar contrasting effects were observed after lateral ventricle versus cisternal administration of lysine-vasopressin [269,270]. The inhibitory effects of relaxin on the milk ejection reflex as well as the haemotensive responses elicited by icv administration, were completely different depending on the site of injection $[271,272]$. These findings show that the site of application into the CSF is very important. To study the control of food intake, many additional experiments were performed, aiming at the relative contribution of fore- and hindbrain areas, with specific administration of a wide variety of substances into either the $3^{\text {rd }}$ or the $4^{\text {th }}$ ventricle, combined with or without occlusion of the cerebral aqueduct. It is beyond the scope of the present review to discuss these in detail, but it is clear that factors flowing in the CSF will reach the $4^{\text {th }}$ ventricle region and influence brainstem areas like area postrema and the solitary complex that control food intake. Hypothalamic and hindbrain melanocortin receptors play an important role $[273,274]$ and the hindbrain relationships with the POMC neurons have been extensively explored [275-279].

In addition to the contributions of the hypothalamomedullary projections, however, the flowing CSF deserves more attention as a medium for sending messages into the brainstem. ARH-activation induces more than 15fold increases in $\beta$-END in the CSF [176], and the CSF transports these products to the effective sites in the mesencephalic central gray region [146,147,177,280-282]. On the other hand, deep brain stimulation in the periventricular gray region, in patients suffering chronic pain, resulted in two- to threefold increases in CSF levels of $\beta$-END in the rostral horn of the lateral ventricle [177]. This raises the question how far this increase is the result of terminal release of $\beta$-END from the mesencephalic opiocortin fibers. It is possible that the electrodes also activated the $\beta$-END cell bodies antidromically, inducing additional dendritic release in the arcuate nucleus.

Finally, since POMC seems to be released into the $3^{\text {rd }}$ ventricular CSF in amounts at least 10 times larger than the peptide derivatives $[196,197]$, it might be rewarding to study volume transmission via the CSF towards the dorsal and ventral hindbrain, as an active mechanism to support neuronal transmission of information. Without exception, all authors of above cited papers conclude that different populations of neurons, bearing different types of receptors, are responsible for the differential effects after local ventricular administration. Concerning $\beta$-END, having different effects on sexual behavior, food intake and pain regulating mechanisms, it is clear that widely divergent brain areas play a major role, from amygdala and rostral hypothalamic sites to midbrain and caudal brainstem sites. The quality of messages, delivered via the CSF, would improve considerably if substances can be delivered at optimal locations in the ventricular system. The high density of POMC-fibers, surrounding the ventricular system, suggests that they are in an excellent position to do so.

There is no direct experimental evidence available that $\beta$-END can be released by specific opiocortin terminals at other ventricular sites than the lower part of the $3^{\text {rd }}$ ventricle, surrounded by the arcuate nucleus. Maybe the use of larger mammals, like sheep or even cows, is 
necessary to obtain experimental evidence for an addressing system with specific behavioral effects. Using sheep, has turned out to be very fruitful in studies concerning release and circulation patterns of melatonin $[62,64,66]$ and GnRH $[57,63,283,284]$. The most convincing evidence would be obtained if it could be shown that the distribution of POMC-concentrations over the different parts of the ventricular system are not identical under different conditions, like feeding, sexual behavior, or suffering from a painful stimulus.

\section{The periaqueductal gray and other regions as targets for the $\beta$-END-flow}

The population of POMC neurons is apparently able to produce massive amounts of $\beta$-END which is released into the $3^{\text {rd }}$ ventricle, to reach the cerebral aqueduct via the CSF flow and to influence the periaqueductal gray (PAG) region of the mesencephalon $[146,148,176]$. This region is closely located to the CSF source, the $\mathrm{ARH}$, and is traversed by numerous POMC fibers $[11,68,70,73-76,89,90,93,210]$. We have discussed previously that neuronal connections with axonal varicosities may mutually support each other via short-term synaptic transmission and via mid-term (up to a few minutes) transport of CSF messages for brain areas, especially those surrounding the ventricular system, as fast axonal release of $\beta$-END from the varicosities in the PAG will penetrate the intercellular space between the PAG-neurons. Slightly later $\beta$-END released in the ventral part of the $3^{\text {rd }}$ ventricle will arrive with the flow of the CSF to the PAG. When local levels start to diminish after the instantaneous release, the elevated CSF levels arriving from the ARH start diffusing into the surrounding tissue to sustain and prolong the local behavioral effects of elevated $\beta$-END levels. This enables the target circuitry to be programmed in a flexible way: a different cocktail of neuropeptides could induce different functionalities of the circuit, by modifying simultaneously a relevant set of parameters.

\section{Conclusions}

In summary the evidence reviewed here suggests that the combination of axonal release of $\beta$-END in specific brain areas and its transmission via the CSF vary according to brain region. The varicose fibers surrounding the ventricular system allow short- as well as long-distance VT. The axonal messages of subgroups of $\beta$-END neurons are targeting specific destinations. The CSF-messages, released from the mediobasal hypothalamus, will arrive with some delay at the downstream brain areas, supporting and extending the effects of axonal messages.

We conclude that $\beta$-END, released into the flowing CSF, may have effects on distant brain regions where they affect a variety of behaviors relating to reward mechanisms and motivational and mental states, and lead to stress-reduction and homeostatic balance.

\section{Abbreviations}

5-HT: Serotonin; ACTH: Adreno-corticotropic hormone; a-MSH: a-melanocytestimulating hormone; ARH: Arcuate nucleus of the hypothalamus;

B-END: Beta endorphin; BBB: Blood-brain-barrier; CNS: Central nervous system; CRH: Corticotropin releasing hormone; CSF: Cerebrospinal fluid; GABA: $y$-aminobutyric acid; GnRH: Gonadotropin releasing hormone; icv: Intracerebroventricular (administration); NTS: Nucleus of the solitary tract; OT: Oxytocin; PAG: Periaqueductal gray region of the midbrain; POMC: Pro-opio-melano-cortin containing neurons or fibers; VT: Volume transmission

\section{Competing interests}

The authors declare that they have no competing interests.

\section{Authors' contributions}

JGV: $80 \%$, composition, contents, writing; HB: 15\%, composition, discussion, improvements and corrections; POG: 5\%: discussion and general

improvements; All authors have read and approved the final version of the manuscript.

\section{Author details}

'Department of Anatomy (109), University Medical Center St. Radboud, PO Box 9101, 6500, HB, Nijmegen, the Netherlands. ${ }^{2}$ Department of

Psychopharmacology, UIPS, University of Utrecht, Utrecht, the Netherlands. ${ }^{3}$ Department of Neuroscience, section Anatomy, University Medical Center Groningen, University of Groningen, Groningen, the Netherlands. ${ }^{4}$ Faculty of Science, Radboud University, Nijmegen, the Netherlands.

Received: 10 April 2012 Accepted: 7 July 2012

Published: 10 August 2012

\section{References}

1. Agnati LF, Cortelli P, Biagini G, Bjelke B, Fuxe K: Different classes of volume transmission signals exist in the central nervous system and are affected by metabolic signals, temperature gradients and pressure waves. Neuroreport 1994, 6:9-12.

2. Agnati LF, Guidolin D, Guescini M, Genedani S, Fuxe K: Understanding wiring and volume transmission. Brain Res Rev 2010, 64:137-159.

3. Fuxe K, Dahlstrom AB, Jonsson G, Marcellino D, Guescini M, Dam M, Manger $P$, Agnati $L$ : The discovery of central monoamine neurons gave volume transmission to the wired brain. Prog Neurobiol 2010, 90:82-100.

4. Veening JG, de Jong T, Barendregt HP: Oxytocin-messages via the cerebrospinal fluid: behavioral effects; a review. Physiol Behav 2010, 101:193-210.

5. Frederickson RC, Geary LE: Endogenous opioid peptides: review of physiological, pharmacological and clinical aspects. Prog Neurobiol 1982, 19:19-69.

6. Sapolsky RM: Why zebra's don't get ulcers. 3rd edition. New York: Henry Holt \& Company; 2004

7. Guillemin R, Ling N, Burgus R, Bloom F, Segal D: Characterization of the endorphins, novel hypothalamic and neurohypophysial peptides with opiate-like activity: evidence that they induce profound behavioral changes. Psychoneuroendocrinology 1977, 2:59-62.

8. Guillemin R, Ling N, Lazarus L, Burgus R, Minick S, Bloom F, Nicoll R, Siggins G, Segal D: The endorphins, novel peptides of brain and hypophysial origin, with opiate-like activity: biochemical and biologic studies. Ann N Y Acad Sci 1977, 297:131-157.

9. Bugnon C, Bloch B, Lenys D, Fellmann D: Infundibular neurons of the human hypothalamus simultaneously reactive with antisera against endorphins, ACTH, MSH and beta-LPH. Cell Tissue Res 1979, 199:177-196.

10. Bloch B, Bugnon C, Fellmann D, Lenys D, Gouget A: Neurons of the rat hypothalamus reactive with antisera against endorphins, ACTH, MSH and beta-LPH. Cell Tissue Res 1979, 204:1-15.

11. Nieuwenhuys R: Chemoarchitecture of the Brain. Berlin: Springer; 1985.

12. Akil H, Watson SJ, Berger PA, Barchas JD: Endorphins, beta-LPH, and ACTH: biochemical, pharmacological and anatomical studies. Adv Biochem Psychopharmacol 1978, 18:125-139. 
13. Akil H, Watson SJ, Young E, Lewis ME, Khachaturian $H$, Walker JM: Endogenous opioids: biology and function. Annu Rev Neurosci 1984, 7:223-255.

14. Bloom F, Segal D, Ling N, Guillemin R: Endorphins: profound behavioral effects in rats suggest new etiological factors in mental illness. Science 1976, 194:630-632

15. Davis BA, Fitzgerald ME, Brown JL, Amstalden KA, Coolen LM: Activation of POMC neurons during general arousal but not sexual behavior in male rats. Behav Neurosci 2007, 121:1012-1022.

16. Margules DL, Moisset B, Lewis MJ, Shibuya H, Pert CB: beta-Endorphin is associated with overeating in genetically obese mice (ob/ob) and rats (fa/fa). Science 1978, 202:988-991.

17. King MG, Kastin AJ, Olson RD, Coy DH: Systemic administration of Met-enkephalin, (D-Ala2)-Met-enkephalin, beta-endorphin, and (D-Ala2)-beta-endorphin: effects on eating, drinking and activity measures in rats. Pharmacol Biochem Behav 1979, 11:407-411.

18. Sanger DJ, McCarthy PS: Differential effects of morphine on food and water intake in food deprived and freely-feeding rats. Psychopharmacology (Berl) 1980, 72:103-106

19. leiri T, Chen HT, Meites J: Effects of morphine and naloxone on serum levels of luteinizing hormone and prolactin in prepubertal male and female rats. Neuroendocrinology 1979, 29:288-292.

20. Baizman ER, Cox BM: Endorphin in rat pituitary glands: its distribution within the gland, and age related changes in gland content in male and female rats. Life Sci 1978, 22:519-526.

21. Olson GA, Olson RD, Kastin AJ, Green MT, Roig-Smith R, Hill CW, Coy DH: Effects of an enkephalin analog on complex learning in the rhesus monkey. Pharmacol Biochem Behav 1979, 11:341-345.

22. Sandman CA, Kastin AJ: The influence of fragments of the LPH chains on learning, memory and attention in animals and man. Pharmacol Ther 1981, 13:39-60.

23. Stein L: Brain endorphins: possible mediators of pleasure and reward. Neurosci Res Program Bull 1978, 16:556-563.

24. Stein L, Belluzzi JD: Brain endorphins: possible role in reward and memory formation. Fed Proc 1979, 38:2468-2472.

25. Grevert $P$, Goldstein A: Effects of naloxone on experimentally induced ischemic pain and on mood in human subjects. Proc Natl Acad Sci U S A 1977, 74:1291-1294.

26. Henderson RS: Endogenous opiates-a progress report. Anaesth Intensive Care 1977, 5:140-145.

27. Ray CD: On opiates, pain, and the nervous system. Neurosurgery 1977, 1:188-189.

28. Basbaum Al, Fields HL: Endogenous pain control mechanisms: review and hypothesis. Ann Neurol 1978, 4:451-462.

29. Fields HL, Basbaum Al: Brainstem control of spinal pain-transmission neurons. Annu Rev Physiol 1978, 40:217-248.

30. Almay BG, Johansson F, Von Knorring L, Terenius L, Wahlstrom A: Endorphins in chronic pain. I. Differences in CSF endorphin levels between organic and psychogenic pain syndromes. Pain 1978, 5:153-162.

31. Terenius $L$ : Significance of endorphins in endogenous antinociception. Adv Biochem Psychopharmacol 1978, 18:321-332.

32. Laubie M, Schmitt $H$, Vincent M, Remond G: Central cardiovascular effects of morphinomimetic peptides in dogs. Eur J Pharmacol 1977, 46:67-71.

33. Bolme P, Fuxe K, Agnati LF, Bradley R, Smythies J: Cardiovascular effects of morphine and opioid peptides following intracisternal administration in chloralose-anesthetized rats. Eur J Pharmacol 1978, 48:319-324.

34. Panksepp J, Vilberg T, Bean NJ, Coy DH, Kastin AJ: Reduction of distress vocalization in chicks by opiate-like peptides. Brain Res Bull 1978, 3:663-667.

35. Rossier J, French ED, Rivier C, Ling N, Guillemin R, Bloom FE: Foot-shock induced stress increases beta-endorphin levels in blood but not brain. Nature 1977, 270:618-620.

36. Guillemin R, Vargo T, Rossier J, Minick S, Ling N, Rivier C, Vale W, Bloom F: beta-Endorphin and adrenocorticotropin are selected concomitantly by the pituitary gland. Science 1977, 197:1367-1369.

37. Rossier J, Guillemin R, Bloom F: Foot shock induced stress decreases leu5-enkephalin immunoreactivity in rat hypothalamus. Eur J Pharmacol 1978, 48:465-466.

38. Abbruscato TJ, Thomas SA, Hruby VJ, Davis TP: Brain and spinal cord distribution of biphalin: correlation with opioid receptor density and mechanism of CNS entry. J Neurochem 1997, 69:1236-1245.
39. Skipor J, Thiery JC: The choroid plexus-cerebrospinal fluid system: undervaluated pathway of neuroendocrine signaling into the brain. Acta Neurobiol Exp (Wars) 2008, 68:414-428.

40. Reiber H: Proteins in cerebrospinal fluid and blood: barriers, CSF flow rate and source-related dynamics. Restor Neurol Neurosci 2003, 21:79-96.

41. Stoodley MA, Jones NR, Brown CJ: Evidence for rapid fluid flow from the subarachnoid space into the spinal cord central canal in the rat. Brain Res 1996, 707:155-164.

42. Stoodley MA, Brown SA, Brown CJ, Jones NR: Arterial pulsation-dependent perivascular cerebrospinal fluid flow into the central canal in the sheep spinal cord. J Neurosurg 1997, 86:686-693.

43. Cifuentes M, Fernandez LP, Perez J, Perez-Figares JM, Rodriguez EM: Distribution of intraventricularly injected horseradish peroxidase in cerebrospinal fluid compartments of the rat spinal cord. Cell Tissue Res 1992, 270:485-494.

44. Banks WA, Kastin AJ: Saturable transport of peptides across the blood-brain barrier. Life Sci 1987, 41:1319-1338.

45. Banks WA, Kastin AJ, Ehrensing CA: Endogenous peptide Tyr-Pro-Trp-Gly$\mathrm{NH} 2$ (Tyr-W-MIF-1) is transported from the brain to the blood by peptide transport system-1. J Neurosci Res 1993, 35:690-695.

46. King M, Su W, Chang A, Zuckerman A, Pasternak GW: Transport of opioids from the brain to the periphery by P-glycoprotein: peripheral actions of central drugs. Nat Neurosci 2001, 4:268-274.

47. Nicholson C: Signals that go with the flow. Trends Neurosci 1999, 22:143-145.

48. Sewards TV, Sewards MA: Representations of motivational drives in mesial cortex, medial thalamus, hypothalamus and midbrain. Brain Res Bull 2003, 61:25-49.

49. Sewards TV, Sewards MA: Fear and power-dominance motivation: proposed contributions of peptide hormones present in cerebrospinal fluid and plasma. Neurosci Biobehav Rev 2003, 27:247-267.

50. Fuxe K, Rivera A, Jacobsen KX, Hoistad M, Leo G, Horvath TL, Staines W, De la Calle A, Agnati LF: Dynamics of volume transmission in the brain. Focus on catecholamine and opioid peptide communication and the role of uncoupling protein 2. J Neural Transm 2005, 112:65-76.

51. Fuxe K, Li XM, Bjelke B, Hedlund PB, Biagini G, Agnati LF: Possible mechanisms for the powerful actions of neuropeptides. Ann N Y Acad Sci 1994, 739:42-59.

52. Fuxe $K$, Dahlstrom A, Hoistad M, Marcellino D, Jansson A, Rivera A, Diaz-Cabiale Z, Jacobsen K, Tinner-Staines B, Hagman B, et al: From the Golgi-Cajal mapping to the transmitter-based characterization of the neuronal networks leading to two modes of brain communication: wiring and volume transmission. Brain Res Rev 2007, 55:17-54.

53. Bjelke B, Stromberg I, O'Connor WT, Andbjer B, Agnati LF, Fuxe K: Evidence for volume transmission in the dopamine denervated neostriatum of the rat after a unilateral nigral 6-OHDA microinjection. Studies with systemic D-amphetamine treatment. Brain Res 1994, 662:11-24.

54. Agnati LF, Leo G, Zanardi A, Genedani S, Rivera A, Fuxe K, Guidolin D: Volume transmission and wiring transmission from cellular to molecular networks: history and perspectives. Acta Physiol (Oxf) 2006, 187:329-344.

55. Agnati LF, Fuxe K: Volume transmission as a key feature of information handling in the central nervous system possible new interpretative value of the Turing's B-type machine. Prog Brain Res 2000, 125:3-19.

56. Agnati LF, Bjelke B, Fuxe K: Volume versus wiring transmission in the brain: a new theoretical frame for neuropsychopharmacology. Med Res Rev 1995, 15:33-45.

57. Caraty A, Skinner DC: Gonadotropin-releasing hormone in third ventricular cerebrospinal fluid: endogenous distribution and exogenous uptake. Endocrinology 2008, 149:5227-5234

58. Faulconbridge LF, Grill HJ, Kaplan JM: Distinct forebrain and caudal brainstem contributions to the neuropeptide $Y$ mediation of ghrelin hyperphagia. Diabetes 2005, 54:1985-1993.

59. Flynn FW: Fourth ventricle bombesin injection suppresses ingestive behaviors in rats. Am J Physiol 1989, 256:R590-R596.

60. Grill HJ, Carmody JS, Amanda Sadacca L, Williams DL, Kaplan JM: Attenuation of lipopolysaccharide anorexia by antagonism of caudal brain stem but not forebrain GLP-1-R. Am J Physiol 2004, 287:R1190-R1193.

61. Ritter RC, Slusser PG, Stone S: Glucoreceptors controlling feeding and blood glucose: location in the hindbrain. Science 1981, 213:451-452. 
62. Skinner DC, Malpaux B: High melatonin concentrations in third ventricular cerebrospinal fluid are not due to Galen vein blood recirculating through the choroid plexus. Endocrinology 1999, 140:4399-4405.

63. Skinner DC, Malpaux B, Delaleu B, Caraty A: Luteinizing hormone (LH)-releasing hormone in third ventricular cerebrospinal fluid of the ewe: correlation with LH pulses and the LH surge. Endocrinology 1995, 136:3230-3237.

64. Tricoire H, Locatelli A, Chemineau P, Malpaux B: Melatonin enters the cerebrospinal fluid through the pineal recess. Endocrinology 2002, 143:84-90.

65. Tricoire H, Moller M, Chemineau P, Malpaux B: Origin of cerebrospinal fluid melatonin and possible function in the integration of photoperiod. Reprod Supp/ 2003, 61:311-321.

66. Malpaux B, Daveau A, Maurice-Mandon F, Duarte G, Chemineau P: Evidence that melatonin acts in the premammillary hypothalamic area to control reproduction in the ewe: presence of binding sites and stimulation of luteinizing hormone secretion by in situ microimplant delivery. Endocrinology 1998, 139:1508-1516.

67. Knigge KM, Joseph SA: Anatomy of the opioid-systems of the brain. Can J Neurol Sci 1984, 11:14-23.

68. Bloom F, Battenberg E, Rossier J, Ling N, Guillemin R: Neurons containing beta-endorphin in rat brain exist separately from those containing enkephalin: immunocytochemical studies. Proc Natl Acad Sci U S A 1978, 75:1591-1595.

69. Watson SJ, Akil H: alpha-MSH in rat brain: occurrence within and outside of beta-endorphin neurons. Brain Res 1980, 182:217-223.

70. Mezey E, Kiss JZ, Mueller GP, Eskay R, O'Donohue TL, Palkovits M: Distribution of the pro-opiomelanocortin derived peptides, adrenocorticotrope hormone, alpha-melanocyte-stimulating hormone and beta-endorphin (ACTH, alpha-MSH, beta-END) in the rat hypothalamus. Brain Res 1985, 328:341-347.

71. Tranchand-Bunel D, Delbende C, Guy J, Jegou S, Jenks BJ, Mocaer E, Pelletier G, Vaudry H: Pro-opiomelanocortin neuronal systems. Rev Neurol (Paris) 1987, 143:471-489.

72. McGinty JF, Bloom FE: Double immunostaining reveals distinctions among opioid peptidergic neurons in the medial basal hypothalamus. Brain Res 1983, 278:145-153.

73. Ibata Y, Kawakami F, Okamura H, Obata-Tsuto HL, Morimoto N, Zimmerman EA: Light and electron microscopic immunocytochemistry of betaendorphin/beta-LPH-like immunoreactive neurons in the arcuate nucleus and surrounding areas of the rat hypothalamus. Brain Res 1985, 341:233-242.

74. Buma P, Veening J, Hafmans $T$, Joosten H, Nieuwenhuys R: Ultrastructure of the periaqueductal grey matter of the rat: an electron microscopical and horseradish peroxidase study. J Comp Neurol 1992, 319:519-535.

75. Buma P, Veening J, Nieuwenhuys R: Ultrastructural Characterization of Adrenocorticotrope Hormone (ACTH) Immunoreactive Fibres in the Mesencephalic Central Grey Substance of the Rat. Eur J Neurosci 1989, 1:659-672.

76. Finley JC, Lindstrom P, Petrusz P: Immunocytochemical localization of beta-endorphin-containing neurons in the rat brain. Neuroendocrinology 1981, 33:28-42.

77. Calle M: Integrative Physiology and Communication in the Amphibian brain: Radboud University, Nijmegen, Depts of Cellular animal Physiology/ Computational Sciences; 2006.

78. Calle M, Claassen IE, Veening JG, Kozicz T, Roubos EW, Barendregt HP: Opioid peptides, CRF, and urocortin in cerebrospinal fluid-contacting neurons in Xenopus laevis. Ann N Y Acad Sci 2005, 1040:249-252.

79. Rodriguez EM, Blazquez JL, Guerra M: The design of barriers in the hypothalamus allows the median eminence and the arcuate nucleus to enjoy private milieus: the former opens to the portal blood and the latter to the cerebrospinal fluid. Peptides 2010, 31:757-776

80. Chen YY, Pelletier G: Demonstration of contacts between proopiomelanocortin neurons in the rat hypothalamus. Neurosci Lett 1983, 43:271-276.

81. Pelletier G, Leclerc R, Saavedra JM, Brownstein MJ, Vaudry H, Ferland L, Labrie F: Distribution of beta-lipotropin (beta-LPH), adrenocorticotropin (ACTH) and alpha-melanocyte-stimulating hormone (alpha-MSH) in the rat brain. I. Origin of the extrahypothalamic fibers. Brain Res 1980, 192:433-440.
82. Barnea A, Cho G, Pilotte NS, Porter JC: Regional differences in the molecular weight profiles of corticotropin and alpha-melanotropin the hypothalamus. Endocrinology 1981, 108:150-156.

83. Dores RM, Khachaturian H, Watson SJ, Akil H: Localization of neurons containing pro-opiomelanocortin-related peptides in the hypothalamus and midbrain of the lizard, Anolis carolinensis: evidence for region-specific processing of beta-endorphin. Brain Res 1984, 324:384-389.

84. Swanson LW: Biochemical switching in hypothalamic circuits mediating responses to stress. Prog Brain Res 1991, 87:181-200.

85. Swanson LW, Sawchenko PE, Lind RW: Regulation of multiple peptides in CRF parvocellular neurosecretory neurons: implications for the stress response. Prog Brain Res 1986, 68:169-190.

86. Swanson LW, Simmons DM: Differential steroid hormone and neural influences on peptide mRNA levels in $\mathrm{CRH}$ cells of the paraventricular nucleus: a hybridization histochemical study in the rat. $J$ Comp Neurol 1989, 285:413-435

87. Mulders WH, Meek J, Hafmans TG, Cools AR: Plasticity in the stressregulating circuit: decreased input from the bed nucleus of the stria terminalis to the hypothalamic paraventricular nucleus in Wistar rats following adrenalectomy. Eur J Neurosci 1997, 9:2462-2471.

88. Van der Horst VG, Holstege G: Sensory and motor components of reproductive behavior: pathways and plasticity. Behav Brain Res 1998, 92:157-167.

89. Douglas AJ, Bicknell RJ, Leng G, Russell JA, Meddle SL: Beta-endorphin cells in the arcuate nucleus: projections to the supraoptic nucleus and changes in expression during pregnancy and parturition. J Neuroendocrinol 2002, 14:768-777.

90. Watson SJ, Richard CW III, Barchas JD: Adrenocorticotropin in rat brain: immunocytochemical localization in cells and axons. Science 1978, 200:1180-1182.

91. Watson SJ, Barchas JD, Li CH: beta-Lipotropin: localization of cells and axons in rat brain by immunocytochemistry. Proc Natl Acad Sci U S A 1977, 74:5155-5158.

92. Knigge KM, Joseph SA, Nocton J: Topography of the ACTHimmunoreactive neurons in the basal hypothalamus of the rat brain. Brain Res 1981, 216:333-341.

93. Romagnano MA, Joseph SA: Immunocytochemical localization of ACTH1-39 in the brainstem of the rat. Brain Res 1983, 276:1-16.

94. Sawchenko PE, Swanson LW, Joseph SA: The distribution and cells of origin of ACTH(1-39)-stained varicosities in the paraventricular and supraoptic nuclei. Brain Res 1982, 232:365-374.

95. Joseph SA: Immunoreactive adrenocorticotropin in rat brain: a neuroanatomical study using antiserum generated against synthetic ACTH. Am J Anat 1980, 158:533-548.

96. Yoshida M, Taniguchi Y: Projection of pro-opiomelanocortin neurons from the rat arcuate nucleus to the midbrain central gray as demonstrated by double staining with retrograde labeling and immunohistochemistry. Arch Histol Cytol 1988, 51:175-183.

97. Pretel S, Piekut DT: ACTH and enkephalin axonal input to paraventricular neurons containing c-fos-like immunoreactivity. Synapse 1991, 8:100-106.

98. Hornby PJ, Piekut DT: Anatomical evidence for interaction of ACTH1-39 immunostained fibers and hypothalamic paraventricular neurons that project to the dorsal vagal complex. Histochemistry 1988, 90:201-206.

99. Piekut DT: Interactions of immunostained ACTH1-39 fibers and CRF neurons in the paraventricular nucleus of rat hypothalamus: application of avidin-glucose oxidase to dual immunostaining procedures. $J$ Histochem Cytochem 1987, 35:261-265.

100. Piekut DT: Relationship of ACTH1-39-immunostained fibers and magnocellular neurons in the paraventricular nucleus of rat hypothalamus. Peptides 1985, 6:883-890.

101. Kawano H, Masuko S: beta-endorphin-, adrenocorticotrophic hormoneand neuropeptide $Y$-containing projection fibers from the arcuate hypothalamic nucleus make synaptic contacts on to nucleus preopticus medianus neurons projecting to the paraventricular hypothalamic nucleus in the rat. Neuroscience 2000, 98:555-565.

102. Joseph SA, Pilcher WH, Knigge KM: Anatomy of the corticotropin-releasing factor and opiomelanocortin systems of the brain. Fed Proc 1985, 44:100-107.

103. Wilcox JN, Roberts JL, Chronwall BM, Bishop JF, Odonohue T: Localization of Proopiomelanocortin Messenger-Rna in Functional Subsets of 
Neurons Defined by Their Axonal Projections. J Neurosci Res 1986, 16:89-96.

104. Veening JG, Buma P, ter Horst GJ, Roeling TAP, Luiten PGM, Nieuwenhuys R: Hypothalamic projections to the PAG in the rat: topographical, immunoelectronmicroscopical and functional aspects. In The Midbrain Periaqueductal Gray Matter. Edited by Depaulis A, Bandler R. New York: Plenum Press; 1991:387-415.

105. Joseph SA, Pilcher WH, Bennett-Clarke C: Immunocytochemical localization of ACTH perikarya in nucleus tractus solitarius: evidence for a second opiocortin neuronal system. Neurosci Lett 1983, 38:221-225.

106. Joseph SA, Michael GJ: Efferent ACTH-IR opiocortin projections from nucleus tractus solitarius: a hypothalamic deafferentation study. Peptides 1988, 9:193-201.

107. Tsou K, Khachaturian H, Akil H, Watson SJ: Immunocytochemical localization of pro-opiomelanocortin-derived peptides in the adult rat spinal cord. Brain Res 1986, 378:28-35.

108. Bloom F, Battenberg E, Rossier J, Ling N, Leppaluoto J, Vargo TM, Guillemin $R:$ Endorphins are located in the intermediate and anterior lobes of the pituitary gland, not in the neurohypophysis. Life Sci 1977, 20:43-47.

109. Khachaturian H, Lewis ME, Schafer MK, Watson SJ: Anatomy of the CNS opioid systems. Trends Neurosci 1985, 8:111-119.

110. Rossier J, Vargo TM, Minick S, Ling N, Bloom FE, Guillemin R: Regional dissociation of beta-endorphin and enkephalin contents in rat brain and pituitary. Proc Natl Acad Sci U S A 1977, 74:5162-5165.

111. de Kloet ER, Palkovits M, Mezey E: Opiocortin peptides: localization, source and avenues of transport. Pharmacol Ther 1981, 12:321-351.

112. Howe A: The mammalian pars intermedia: a review of its structure and function. J Endocrinol 1973, 59:385-409.

113. O'Donohue TL, Dorsa DM: The opiomelanotropinergic neuronal and endocrine systems. Peptides 1982, 3:353-395.

114. Silman RE, Chard T, Landon J, Lowry PJ, Smith I, Young IM: ACTH and MSH peptides in the human adult and fetal pituitary gland. Front Horm Res 1977, 4:179-187.

115. Houghten RA, Swann RW, Li CH: beta-Endorphin: stability, clearance behavior, and entry into the central nervous system after intravenous injection of the tritiated peptide in rats and rabbits. Proc Natl Acad Sci US A 1980, 77:4588-4591.

116. Barna I, Sweep CG, Veldhuis HD, Wiegant VM, De Wied D: Effects of pituitary beta-endorphin secretagogues on the concentration of betaendorphin in rat cerebrospinal fluid: evidence for a role of vasopressin in the regulation of brain beta-endorphin release. Neuroendocrinology 1990, 51:104-110.

117. De Riu PL, Petruzzi V, Caria MA, Mameli O, Casu AR, Nuvoli S, Spanu A, Madeddu G: Beta-endorphin and cortisol levels in plasma and CSF following acute experimental spinal traumas. Physiol Behav 1997, 62:1-5.

118. Guo ZM, Liu CT, Peters CJ: Possible involvement of endogenous betaendorphin in the pathophysiological mechanisms of Pichinde virusinfected guinea pigs. Proc Soc Exp Biol Med 1992, 200:343-348.

119. Yamamoto T, Sako N, Maeda S: Effects of taste stimulation on beta-endorphin levels in rat cerebrospinal fluid and plasma. Physiol Behav 2000, 69:345-350.

120. Barna I, Sweep CG, Veldhuis HD, Wiegant VM: Differential effects of cisterna magna cannulation on beta-endorphin levels in rat plasma and cerebrospinal fluid. Acta Endocrinol (Copenh) 1988, 117:517-524.

121. Nakao K, Nakai Y, Oki S, Matsubara S, Konishi T, Nishitani H, Imura H: Immunoreactive beta-endorphin in human cerebrospinal fluid. I Clin Endocrinol Metab 1980, 50:230-233.

122. Facchinetti F, Petraglia F, Nappi G, Martignoni E, Antoni G, Parrini D, Genazzani AR: Different patterns of central and peripheral beta EP, beta LPH and ACTH throughout life. Peptides 1983, 4:469-474.

123. Nakao K, Nakai Y, Jingami H, Oki S, Fukata J, Imura H: Substantial rise of plasma beta-endorphin levels after insulin-induced hypoglycemia in human subjects. J Clin Endocrinol Metab 1979, 49:838-841.

124. Nakao K, Nakai Y, Oki S, Horii K, Imura H: Presence of immunoreactive beta-endorphin in normal human plasma: a concomitant release of beta-endorphin with adrenocorticotropin after metyrapone administration. J Clin Invest 1978, 62:1395-1398.

125. Nappi G, Facchinetti F, Bono G, Petraglia F, Sinforiani E, Genazzani AR: CSF and plasma levels of pro-opiomelanocortin-related peptides in reversible ischaemic attacks and strokes. J Neurol Neurosurg Psychiatry 1986, 49:17-21.
126. Brunani A, Invitti C, Dubini A, Piccoletti R, Bendinelli P, Maroni P, Pezzoli G, Ramella G, Calogero A, Cavagnini F: Cerebrospinal fluid and plasma concentrations of SRIH, beta-endorphin, CRH, NPY and GHRH in obese and normal weight subjects. Int J Obes Relat Metab Disord 1995, 19:17-21.

127. Oki S, Nakai Y, Nakao K, Imura H: Plasma beta-endorphin responses to somatostatin, thyrotropin-releasing hormone, or vasopressin in Nelson's syndrome. J Clin Endocrinol Metab 1980, 50:194-197.

128. Steinbrook RA, Carr DB, Datta S, Naulty JS, Lee C, Fisher J: Dissociation of plasma and cerebrospinal fluid beta-endorphin-like immunoactivity levels during pregnancy and parturition. Anesth Analg 1982, 61:893-897.

129. Radzikowska B, Szczudlik A, Lypka A: Beta-endorphin levels in the blood and cerebrospinal fluid in humans. Neurol Neurochir Pol 1985, 19:281-285.

130. Adams ML, Morris DL, Brase DA, Dewey WL: Stereoselective effect of morphine on antinociception and endogenous opioid peptide levels in plasma but not cerebrospinal fluid of dogs. Life Sci 1991, 48:917-924

131. Matejec R, Ruwoldt R, Bodeker RH, Hempelmann G, Teschemacher H: Release of beta-endorphin immunoreactive material under perioperative conditions into blood or cerebrospinal fluid: significance for postoperative pain? Anesth Analg 2003, 96:481-486. table of contents.

132. Spaziante R, Merola B, Colao A, Gargiulo G, Cafiero T, Irace C, Rossi E, Oliver C, Lombardi G, Mazzarella B, et al: Beta-endorphin concentrations both in plasma and in cerebrospinal fluid in response to acute painful stimuli. J Neurosurg Sci 1990, 34:99-106.

133. Spinazzola F, Barletta C, Demartino G, Martini F, Natili S, Noto P, Ferri F, Tossini G, Visco G: Beta-endorphins ACTH and cortisol in CSF and plasma of HIV infected patients. Riv Eur Sci Med Farmacol 1995, 17:161-165.

134. Barreca T, Siani C, Franceschini R, Francaviglia N, Messina V, Perria C, Rolandi E: Diurnal beta-endorphin changes in human cerebrospinal fluid. Life SC 1986, 38:2263-2267.

135. Hamel E: CSF-endorphines in acute and chronic brain lesions. Neurosurg Rev 1988, 11:193-199.

136. Lopez JA, Peran F, Altuzarra A, Garrido F, Arjona V: Correlation between plasmatic and CSF beta-endorphin levels. Neurol Res 1984, 6:118-120.

137. Facchinetti F, Petraglia F, Sances G, Garuti C, Tosca P, Nappi G, Genazzani AR: Dissociation between CSF and plasma B-endorphin in major depressive disorders: evidence for a different regulation. J Endocrinol Invest 1986, 9:11-14.

138. Facchinetti F, Sforza G, Amidei M, Cozza C, Petraglia F, Montanari C, Genazzani AR: Central and peripheral beta-endorphin response to transcutaneous electrical nerve stimulation. NIDA Res Monogr 1986, 75:555-558.

139. Morales AB, Vives F, Ros I, Mora F: Plasma and CSF levels of immunoreactive beta-endorphin in algic peaks of patients with herniated intervertebral discs. Rev Esp Fisiol 1988, 44:21-25.

140. Smith R, Owens PC, Lovelock M, Chan EC, Falconer J: Acute hemorrhagic stress in conscious sheep elevates immunoreactive beta-endorphin in plasma but not in cerebrospinal fluid. Endocrinology 1986, 118:2572-2576.

141. Burbach JP, De Hoop MJ, Schmale H, Richter D, De Kloet ER, Ten Haaf JA, De Wied D: Differential responses to osmotic stress of vasopressin-neurophysin mRNA in hypothalamic nuclei. Neuroendocrinology 1984, 39:582-584.

142. Burbach JP, Loeber JG, Verhoef J, de Kloet ER, van Ree JM, de Wied D: Schizophrenia and degradation of endorphins in cerebrospinal fluid. Lancet 1979, 2:480-481.

143. Ambach G, Palkovits M, Szentagothai J: Blood supply of the rat hypothalamus. IV. Retrochiasmatic area, median eminence, arcuate nucleus. Acta Morphol Acad Sci Hung 1976, 24:93-119.

144. Oliver C, Mical RS, Porter JC: Hypothalamic-pituitary vasculature: evidence for retrograde blood flow in the pituitary stalk. Endocrinology 1977, 101:598-604.

145. Gao B, Hagenbuch B, Kullak-Ublick GA, Benke D, Aguzzi A, Meier PJ: Organic anion-transporting polypeptides mediate transport of opioid peptides across blood-brain barrier. J Pharmacol Exp Ther 2000, 294:73-79.

146. Bach FW, Yaksh TL: Release into ventriculo-cisternal perfusate of betaendorphin- and Met-enkephalin-immunoreactivity: effects of electrical stimulation in the arcuate nucleus and periaqueductal gray of the rat. Brain Res 1995, 690:167-176.

147. Bach FW, Yaksh TL: Release of beta-endorphin immunoreactivity from brain by activation of a hypothalamic N-methyl-D-aspartate receptor. Neuroscience 1995, 65:775-783. 
148. MacMillan SJ, Mark MA, Duggan AW: The release of beta-endorphin and the neuropeptide-receptor mismatch in the brain. Brain Res 1998, 794:127-136.

149. Dias RD, Perry ML, Carrasco MA, Izquierdo I: Effect of electroconvulsive shock on beta-endorphin immunoreactivity of rat brain, pituitary gland, and plasma. Behav Neural Biol 1981, 32:265-268.

150. Kosten TR, Kreek MJ, Swift C, Carney MK, Ferdinands L: Beta endorphin levels in CSF during methadone maintenance. Life Sci 1987, 41:1071-1076.

151. Izquierdo I, Netto CA: Role of beta-endorphin in behavioral regulation. Ann N Y Acad Sci 1985, 444:162-177.

152. Wan RQ, Wiegant VM, de Jong W, de Wied D: Alterations of betaendorphin-like immunoreactivity in CSF following behavioral training using a passive avoidance procedure. Psychoneuroendocrinology 1996, 21:503-513.

153. Sweep CG, Boomkamp MD, Barna I, Logtenberg AW, Wiegant VM: Vasopressin enhances the clearance of beta-endorphin immunoreactivity from rat cerebrospinal fluid. Acta Endocrinol (Copenh) 1990, 122:191-200

154. Sweep CGJ, Barna I, Wiegant VM: Dual effects of vasopressin on the concentration of beta-endorphin immunoreactivity in rat cerebrospinal fluid. Adv Biosci 1989, 75:371-374.

155. Banks WA: The CNS as a target for peptides and peptide-based drugs. Expert Opin Drug Deliv 2006, 3:707-712.

156. Banks WA: Are the extracellular [correction of extracelluar] pathways a conduit for the delivery of therapeutics to the brain? Curr Pharm Des 2004, 10:1365-1370

157. Nieuwenhuys R, Veening JG, van Domburg P: Core and paracores; some new chemoarchitectural entities in the mammalian neuraxis. Acta Morphol Neer SC 1988, 26:131-163.

158. Veening JG, Barendregt HP: The regulation of brain states by neuroactive substances distributed via the cerebrospinal fluid; a review. Cerebrospinal Fluid Res 2010, 7:1.

159. Bjelke B, England R, Nicholson C, Rice ME, Lindberg J, Zoli M, Agnati LF, Fuxe K: Long distance pathways of diffusion for dextran along fibre bundles in brain. Relevance for volume transmission. Neuroreport 1995, 6:1005-1009.

160. Agnati LF, Fuxe K, Zoli M, Ozini I, Toffano G, Ferraguti F: A correlation analysis of the regional distribution of central enkephalin and betaendorphin immunoreactive terminals and of opiate receptors in adult and old male rats. Evidence for the existence of two main types of communication in the central nervous system: the volume transmission and the wiring transmission. Acta Physio/ Scand 1986, 128:201-207.

161. Bjelke B, Fuxe K: Intraventricular beta-endorphin accumulates in DARPP32 immunoreactive tanycytes. Neuroreport 1993, 5:265-268.

162. Fuxe K, Tinner B, Bjelke B, Agnati LF, Verhofstad A, Steinbusch HG, Goldstein M, Hersh L, Kalia M: Monoaminergic and Peptidergic Innervation of the Intermedio-Lateral Horn of the Spinal Cord. Eur J Neurosci 1990, 2:451-460.

163. Hoistad M, Samskog J, Jacobsen KX, Olsson A, Hansson HA, Brodin E, Fuxe K: Detection of beta-endorphin in the cerebrospinal fluid after intrastriatal microinjection into the rat brain. Brain Res 2005 1041:167-180

164. Agnati LF, Fuxe K, Locatelli V, Benfenati F, Zini I, Panerai AE, El Etreby MF, Hokfelt T: Neuroanatomical methods for the quantitative evaluation of coexistence of transmitters in nerve cells. Analysis of the ACTH- and beta-endorphin immunoreactive nerve cell bodies of the mediobasal hypothalamus of the rat. J Neurosci Methods 1982, 5:203-214.

165. Agnati LF, Zoli M, Stromberg I, Fuxe K: Intercellular communication in the brain: wiring versus volume transmission. Neuroscience 1995, 69:711-726.

166. Fuxe K, Agnati LF, Zoli M, Bjelke B, Zini I: Some aspects of the communicational and computational organization of the brain. Acta Physiol Scand 1989, 135:203-216.

167. Rodriguez EM, Blazquez JL, Pastor FE, Pelaez B, Pena P, Peruzzo B, Amat P: Hypothalamic tanycytes: a key component of brain-endocrine interaction. Int Rev Cytol 2005, 247:89-164.

168. Broadwell RD, Brightman MW: Entry of Peroxidase into Neurons of Central and Peripheral Nervous Systems from Extracerebral and Cerebral Blood. J Comp Neurol 1976, 166:257-283.

169. Millhouse OE: A Golgi study of third ventricle tanycytes in the adult rodent brain. Z Zellforsch Mikrosk Anat 1971, 121:1-13.
170. Peruzzo B, Pastor FE, Blazquez JL, Schobitz K, Pelaez B, Amat P, Rodriguez EM: A second look at the barriers of the medial basal hypothalamus. Exp Brain Res 2000, 132:10-26.

171. Rethelyi M: Diffusional Barrier around the Hypothalamic Arcuate Nucleus in the Rat. Brain Res 1984, 307:355-358.

172. Vandenpol AN, Cassidy JR: The Hypothalamic Arcuate Nucleus of Rat - a Quantitative Golgi Analysis. J Comp Neurol 1982, 204:65-98.

173. Leslie FM, Chen Y, Winzer-Serhan UH: Opioid receptor and peptide mRNA expression in proliferative zones of fetal rat central nervous system. Can J Physiol Pharmacol 1998, 76:284-293.

174. Burbach JP: Action of proteolytic enzymes on lipotropins and endorphins: biosynthesis, biotransformation and fate. Pharmacol Ther 1984, 24:321-354.

175. Yamamoto M, Kubota Y, Matsuura M, Homma JY: Antibody titers in the serum of patients vaccinated with the multicomponent vaccine consisting of toxoids of protease, elastase and a common protective antigen (OEP). Kansenshogaku Zasshi 1986, 60:1178-1183.

176. Akil H, Richardson DE, Barchas JD, Li CH: Appearance of beta-endorphin-like immunoreactivity in human ventricular cerebrospinal fluid upon analgesic electrical stimulation. Proc Nat/ Acad Sci U S A 1978, 75:5170-5172.

177. Young RF, Bach FW, Van Norman AS, Yaksh TL: Release of beta-endorphin and methionine-enkephalin into cerebrospinal fluid during deep brain stimulation for chronic pain. Effects of stimulation locus and site of sampling. J Neurosurg 1993, 79:816-825.

178. Izquierdo I, Netto CA, Carrasco MA, Dias RD, Volkmer N: The course of the decrease of hypothalamic beta-endorphin induced by training, and the development of the effect of beta-endorphin on the retrieval of inhibitory avoidance in rats. Braz J Med Biol Res 1985 18:391-395.

179. Ableitner A, Schulz R: Neuroanatomical sites mediating the central actions of beta-endorphin as mapped by changes in glucose utilization: involvement of mu opioid receptors. J Pharmacol Exp Ther 1992, 262:415-423.

180. Sagen J, Wang H, Pappas GD: Adrenal medullary implants in the rat spinal cord reduce nociception in a chronic pain model. Pain 1990, 42:69-79.

181. Siegan JB, Sagen J: Attenuation of formalin pain responses in the rat by adrenal medullary transplants in the spinal subarachnoid space. Pain 1997, 70:279-285

182. Yadid G, Zangen A, Herzberg U, Nakash R, Sagen J: Alterations in endogenous brain beta-endorphin release by adrenal medullary transplants in the spinal cord. Neuropsychopharmacology 2000, 23:709-716.

183. Finegold AA, Mannes AJ, ladarola MJ: A paracrine paradigm for in vivo gene therapy in the central nervous system: treatment of chronic pain. Hum Gene Ther 1999, 10:1251-1257.

184. Leak RK, Moore RY: Innervation of ventricular and periventricular brain compartments. Brain Res 2012, 1463:51-62.

185. Zhang LC, Zeng YM, Ting J, Cao JP, Wang MS: The distributions and signaling directions of the cerebrospinal fluid contacting neurons in the parenchyma of a rat brain. Brain Res 2003, 989:1-8.

186. Vigh B, Silva MJ, Manzano E, Frank CL, Vincze C, Czirok SJ, Szabo A, Lukats A, Szel A: The system of cerebrospinal fluid-contacting neurons. Its supposed role in the nonsynaptic signal transmission of the brain. Histol Histopathol 2004, 19:607-628.

187. Sabatier N, Caquineau C, Dayanithi G, Bull P, Douglas AJ, Guan XMM, Jiang $M$, Van der Ploeg L, Leng G: alpha-melanocyte-stimulating hormone stimulates oxytocin release from the dendrites of hypothalamic neurons while inhibiting oxytocin release from their terminals in the neurohypophysis. J Neurosci 2003, 23:10351-10358.

188. Sabatier N, Caquineau C, Douglas AJ, Leng G: Oxytocin released from magnocellular dendrites - A potential modulator of alpha-melanocytestimulating hormone behavioral actions? Melanocortin System 2003, 994:218-224.

189. Sabatier N, Leng G: Presynaptic actions of endocannabinoids mediate alpha-MSH-induced inhibition of oxytocin cells. Am J Physio/-Reg / 2006, 290:R577-R584.

190. Brunton PJ, Sabatier N, Leng G, Russell JA: Suppressed oxytocin neuron responses to immune challenge in late pregnant rats: a role for endogenous opioids. Eur J Neurosci 2006, 23:1241-1247. 
191. Landgraf R, Neumann ID: Vasopressin and oxytocin release within the brain: a dynamic concept of multiple and variable modes of neuropeptide communication. Front Neuroendocrinol 2004, 25:150-176.

192. Leng G, Ludwig M: Jacques Benoit Lecture. Information processing in the hypothalamus: peptides and analogue computation. J Neuroendocrinol 2006, 18:379-392.

193. Hentges ST: Synaptic regulation of proopiomelanocortin neurons can occur distal to the arcuate nucleus. J Neurophysiol 2007, 97:3298-3304.

194. Bakkali-Kassemi L, El Ouezzani S, Magoul R, Merroun I, Lopez-Jurado M, Errami M: Effects of cannabinoids on neuropeptide $Y$ and betaendorphin expression in the rat hypothalamic arcuate nucleus. $\mathrm{Br} J \mathrm{Nutr}$ 2011, 105:654-660.

195. Krieger DT, Liotta AS, Hauser H, Brownstein MJ: Effect of stress, adrenocorticotropin or corticosteroid treatment, adrenalectomy, or hypophysectomy on hypothalamic immunoreactive adrenocorticotropin concentrations. Endocrinology 1979, 105:737-742.

196. Berrettini WH, Nurnberger JI Jr, Chan JS, Chrousos GP, Gaspar L, Gold PW, Seidah NG, Simmons-Alling S, Goldin LR, Chretien M, et al: Proopiomelanocortin-related peptides in cerebrospinal fluid: a study of manic-depressive disorder. Psychiatry Res 1985, 16:287-302.

197. Tsigos C, Crosby SR, Gibson S, Young RJ, White A: Proopiomelanocortin is the predominant adrenocorticotropin-related peptide in human cerebrospinal fluid. J Clin Endocrinol Metab 1993, 76:620-624.

198. Pritchard LE, Oliver RL, McLoughlin JD, Birtles S, Lawrence CB, Turnbull AV, White A: Proopiomelanocortin-derived peptides in rat cerebrospinal fluid and hypothalamic extracts: evidence that secretion is regulated with respect to energy balance. Endocrinology 2003, 144:760-766.

199. Pritchard LE, Turnbull AV, White A: Pro-opiomelanocortin processing in the hypothalamus: impact on melanocortin signalling and obesity. J Endocrinol 2002, 172:411-421.

200. Pritchard LE, White A: Neuropeptide processing and its impact on melanocortin pathways. Endocrinology 2007, 148:4201-4207.

201. Gessa GL, Fratta W, Melis M, Bertolini A, Ferrari W: Hypothalamic ACTH and MSH levels increase in morphine tolerance and decrease after morphine withdrawal. Eur J Pharmacol 1983, 95:143-144.

202. Vergoni AV, Poggioli R, Facchinetti F, Bazzani C, Marrama D, Bertolini A Tolerance develops to the behavioural effects of ACTH-(1-24) during continuous i.c.v. infusion in rats, and is associated with increased hypothalamic levels of beta-endorphin. Neuropeptides 1989, 14:93-98.

203. Roberts AC, Martensz ND, Hastings MH, Herbert J: The effects of castration, testosterone replacement and photoperiod upon hypothalamic betaendorphin levels in the male Syrian hamster. Neuroscience 1987, 23:1075-1082.

204. Zhang X, Leng G, Feng J: Coherent peptide-mediated activity in a neuronal network controlled by subcellular signaling pathway: experiments and modeling. J Biotechnol 2010, 149:215-225.

205. Chronwall BM: Anatomy and Physiology of the Neuro-Endocrine Arcuate Nucleus. Peptides 1985, 6:1-11.

206. Jirikowski GF, Merchenthaler I, Rieger GE, Stumpf WE: Estradiol target sites immunoreactive for beta-endorphin in the arcuate nucleus of rat and mouse hypothalamus. Neurosci Lett 1986, 65:121-126.

207. Miller MM, Tousignant P, Yang U, Pedvis S, Billiar RB: Effects of age and long-term ovariectomy on the estrogen-receptor containing subpopulations of beta-endorphin-immunoreactive neurons in the arcuate nucleus of female C57BL/6J mice. Neuroendocrinology 1995, 61:542-551.

208. Morrell Jl, McGinty JF, Pfaff DW: A subset of beta-endorphin- or dynorphin-containing neurons in the medial basal hypothalamus accumulates estradiol. Neuroendocrinology 1985, 41:417-426.

209. Thornton JE, Loose MD, Kelly MJ, Ronnekleiv OK: Effects of estrogen on the number of neurons expressing beta-endorphin in the medial basal hypothalamus of the female guinea pig. J Comp Neurol 1994, 341:68-77.

210. Simerly RB, Mccall LD, Watson SJ: Distribution of Opioid-Peptides in the Preoptic Region - Immunohistochemical Evidence for a Steroid-Sensitive Enkephalin Sexual Dimorphism. J Comp Neurol 1988, 276:442-459.

211. Mansour A, Khachaturian $H$, Lewis ME, Akil H, Watson SJ: Anatomy of CNS opioid receptors. Trends Neurosci 1988, 11:308-314.

212. Lewis ME, Pert A, Pert CB, Herkenham M: Opiate receptor localization in rat cerebral cortex. J Comp Neurol 1983, 216:339-358.
213. Lewis ME, Khachaturian H, Watson SJ: Comparative distribution of opiate receptors and three opioid peptide neuronal systems in rhesus monkey central nervous system. Life Sci 1983, 33(Suppl 1):239-242.

214. Zheng SX, Bosch MA, Ronnekleiv OK: mu-opioid receptor mRNA expression in identified hypothalamic neurons. J Comp Neurol 2005, 487:332-344.

215. Atweh SF, Kuhar MJ: Autoradiographic localization of opiate receptors in rat brain. III. The telencephalon. Brain Res 1977, 134:393-405.

216. Atweh SF, Kuhar MJ: Autoradiographic localization of opiate receptors in rat brain. II. The brain stem. Brain Res 1977, 129:1-12.

217. Atweh SF, Kuhar MJ: Autoradiographic localization of opiate receptors in rat brain. I. Spinal cord and lower medulla. Brain Res 1977, 124:53-67.

218. Desjardins GC, Brawer JR, Beaudet A: Distribution of mu, delta, and kappa opioid receptors in the hypothalamus of the rat. Brain Res 1990, 536:114-123.

219. Ding YQ, Kaneko T, Nomura S, Mizuno N: Immunohistochemical localization of mu-opioid receptors in the central nervous system of the rat. J Comp Neurol 1996, 367:375-402.

220. Goodman RR, Snyder SH, Kuhar MJ, Young WS 3rd: Differentiation of delta and mu opiate receptor localizations by light microscopic autoradiography. Proc Natl Acad Sci U S A 1980, 77:6239-6243.

221. McLean S, Rothman RB, Jacobson AE, Rice KC, Herkenham M: Distribution of opiate receptor subtypes and enkephalin and dynorphin immunoreactivity in the hippocampus of squirrel, guinea pig, rat, and hamster. J Comp Neurol 1987, 255:497-510.

222. Jaferi A, Pickel VM: Mu-opioid and corticotropin-releasing-factor receptors show largely postsynaptic co-expression, and separate presynaptic distributions, in the mouse central amygdala and bed nucleus of the stria terminalis. Neuroscience 2009, 159:526-539.

223. Gutstein HB, Mansour A, Watson SJ, Akil H, Fields HL: Mu and kappa opioid receptors in periaqueductal gray and rostral ventromedial medulla. Neuroreport 1998, 9:1777-1781.

224. Wise SP, Herkenham M: Opiate receptor distribution in the cerebral cortex of the Rhesus monkey. Science 1982, 218:387-389.

225. Herkenham M, Pert CB: Light microscopic localization of brain opiate receptors: a general autoradiographic method which preserves tissue quality. J Neurosci 1982, 2:1129-1149.

226. de Gortari P, Mengod G: Dopamine D1, D2 and mu-opioid receptors are co-expressed with adenylyl cyclase 5 and phosphodiesterase 7B mRNAs in striatal rat cells. Brain Res 2010, 1310:37-45.

227. Jenck F, Quirion R, Wise RA: Opioid receptor subtypes associated with ventral tegmental facilitation and periaqueductal gray inhibition of feeding. Brain Res 1987, 423:39-44.

228. Jenck F, Gratton A, Wise RA: Opioid receptor subtypes associated with ventral tegmental facilitation of lateral hypothalamic brain stimulation reward. Brain Res 1987, 423:34-38.

229. Kuhar MJ, De Souza EB, Unnerstall JR: Neurotransmitter receptor mapping by autoradiography and other methods. Annu Rev Neurosci 1986, 9:27-59.

230. Herkenham M: Mismatches between neurotransmitter and receptor localizations in brain: observations and implications. Neuroscience 1987, 23:1-38.

231. Bernstein $H G$, Henning $H$, Seliger N, Baumann B, Bogerts B: Remarkable beta-endorphinergic innervation of human cerebral cortex as revealed by immunohistochemistry. Neurosci Lett 1996, 215:33-36.

232. McGregor A, Herbert J: The effects of beta-endorphin infusions into the amygdala on visual and olfactory sensory processing during sexual behaviour in the male rat. Neuroscience 1992, 46:173-179.

233. McGregor A, Herbert J: Specific effects of beta-endorphin infused into the amygdala on sexual behaviour in the male rat. Neuroscience 1992, 46:165-172

234. Stavy M, Herbert J: Differential effects of beta-endorphin infused into the hypothalamic preoptic area at various phases of the male rat's sexual behaviour. Neuroscience 1989, 30:433-442.

235. Hughes AM, Everitt BJ, Herbert J: Selective effects of beta-endorphin infused into the hypothalamus, preoptic area and bed nucleus of the stria terminalis on the sexual and ingestive behaviour of male rats. Neuroscience 1987, 23:1063-1073.

236. Roth-Deri I, Green-Sadan T, Yadid G: Beta-endorphin and drug-induced reward and reinforcement. Prog Neurobiol 2008, 86:1-21.

237. Monteleone P: New frontiers in endocrinology of eating disorders. Curr Top Behav Neurosci 2011, 6:189-208. 
238. Pecina S, Smith KS: Hedonic and motivational roles of opioids in food reward: implications for overeating disorders. Pharmacol Biochem Behav 2010, 97:34-46.

239. Kringelbach ML, Berridge $\mathrm{KC}$ : The functional neuroanatomy of pleasure and happiness. Discov Med 2010, 9:579-587.

240. Berridge KC, Ho CY, Richard JM, DiFeliceantonio AG: The tempted brain eats: pleasure and desire circuits in obesity and eating disorders. Brain Res 2010, 1350:43-64.

241. Benton D: The plausibility of sugar addiction and its role in obesity and eating disorders. Clin Nutr 2010, 29:288-303.

242. Fulton S: Appetite and reward. Front Neuroendocrinol 2010, 31:85-103.

243. Gosnell BA, Levine AS: Reward systems and food intake: role of opioids. Int J Obes (Lond) 2009, 33(Suppl 2):S54-S58.

244. Mahler SV, Berridge KC: Which cue to "want?" Central amygdala opioid activation enhances and focuses incentive salience on a prepotent reward cue. J Neurosci 2009, 29:6500-6513.

245. Nathan PJ, Bullmore ET: From taste hedonics to motivational drive: central mu-opioid receptors and binge-eating behaviour. Int J Neuropsychopharmacol 2009, 12:1-14.

246. Berridge KC: 'Liking' and 'wanting' food rewards: brain substrates and roles in eating disorders. Physiol Behav 2009, 97:537-550.

247. Reece AS: Hypothalamic opioid-melanocortin appetitive balance and addictive craving. Med Hypoth 2011, 76:132-137.

248. Bandelow B, Schmahl C, Falkai P, Wedekind D: Borderline personality disorder: a dysregulation of the endogenous opioid system? Psychol Rev 2010, 117:623-636

249. Riters LV: Evidence for opioid involvement in the motivation to sing J Chem Neuroanat 2010, 39:141-150.

250. Camacho FJ, Portillo W, Quintero-Enriquez O, Paredes RG: Reward value of intromissions and morphine in male rats evaluated by conditioned place preference. Physiol Behav 2009, 98:602-607.

251. Pfaus JG: Pathways of sexual desire. J Sex Med 2009, 6:1506-1533.

252. Paredes RG: Evaluating the neurobiology of sexual reward. ILAR journal / National Research Council, Institute of Laboratory Animal Resources 2009, 50:15-27.

253. Nocjar C, Panksepp J: Prior morphine experience induces long-term increases in social interest and in appetitive behavior for natural reward. Behav Brain Res 2007, 181:191-199.

254. Kippin TE, van der Kooy D: Excitotoxic lesions of the tegmental pedunculopontine nucleus impair copulation in naive male rats and block the rewarding effects of copulation in experienced male rats. Eur J Neurosci 2003, 18:2581-2591.

255. Pitchers KK, Balfour ME, Lehman MN, Richtand NM, Yu L, Coolen LM: Neuroplasticity in the mesolimbic system induced by natural reward and subsequent reward abstinence. Biol Psychiatr 2010, 67:872-879.

256. Tenk CM, Wilson H, Zhang Q, Pitchers KK, Coolen LM: Sexual reward in male rats: effects of sexual experience on conditioned place preferences associated with ejaculation and intromissions. Horm Behav 2009, 55:93-97.

257. Olivier JD, de Jong TR, Jos Dederen $P$, van Oorschot R, Heeren D, Pattij $T$, Waldinger MD, Coolen LM, Cools AR, Olivier B, Veening JG: Effects of acute and chronic apomorphine on sex behavior and copulation-induced neural activation in the male rat. Eur J Pharmacol 2007, 576:61-76.

258. Coolen LM, Fitzgerald ME, Yu L, Lehman MN: Activation of mu opioid receptors in the medial preoptic area following copulation in male rats. Neuroscience 2004, 124:11-21.

259. Balfour ME, Yu L, Coolen LM: Sexual behavior and sex-associated environmental cues activate the mesolimbic system in male rats. Neuropsychopharmacology 2004, 29:718-730.

260. Nestler EJ: The neurobiology of cocaine addiction. Sci Pract Perspect 2005, 3:4-10.

261. Nestler EJ: Is there a common molecular pathway for addiction? Nat Neurosci 2005, 8:1445-1449.

262. Di Chiara G, Imperato A: Drugs abused by humans preferentially increase synaptic dopamine concentrations in the mesolimbic system of freely moving rats. Proc Natl Acad Sci U S A 1988, 85:5274-5278.

263. Spanagel R, Herz A, Shippenberg TS: Identification of the opioid receptor types mediating beta-endorphin-induced alterations in dopamine release in the nucleus accumbens. Eur J Pharmacol 1990, 190:177-184.
264. Spanagel R, Herz A, Shippenberg TS: The effects of opioid peptides on dopamine release in the nucleus accumbens: an in vivo microdialysis study. J Neurochem 1990, 55:1734-1740.

265. Spanagel R, Weiss F: The dopamine hypothesis of reward: past and current status. Trends Neurosci 1999, 22:521-527.

266. Wilson CA, Hunter AJ: Progesterone stimulates sexual behaviour in female rats by increasing 5 - $\mathrm{HT}$ activity on 5 - $\mathrm{HT} 2$ receptors. Brain Res 1985, 333:223-229.

267. Schulze HG, Gorzalka BB: Low concentrations of oxytocin suppress lordosis when infused into the lateral ventricle of female rats. Endocr Regul 1992, 26:23-27.

268. Gorzalka BB, Heddema GM, Lester GL, Hanson LA: beta-endorphin inhibits and facilitates lordosis behaviour in rats depending on ventricular site of administration. Neuropeptides 1997, 31:517-521.

269. Gunther O, Kovacs GL, Szabo G, Telegdy G: Opposite effects of intraventricular and intracisternal administration of vasopressin on blood pressure in rats. Peptides 1986, 7:539-540.

270. Gunther O, Szabo G, Kovacs GL, Telegdy G: The effect on brain 5-HT of central lysine-vasopressin administration into different cerebral ventricular compartments depends on the site of injection. Neuropeptides 1986, 7:241-245.

271. O'Byrne KT, Eltringham L, Summerlee AJ: Central inhibitory effects of relaxin on the milk ejection reflex of the rat depends upon the site of injection into the cerebroventricular system. Brain Res 1987, 405:80-83.

272. Mumford AD, Parry $L$, Summerlee AJ: Lesion of the subfornical organ affects the haemotensive response to centrally administered relaxin in anaesthetized rats. J Endocrinol 1989, 122:747-755.

273. Skibicka KP, Grill HJ: Hypothalamic and hindbrain melanocortin receptors contribute to the feeding, thermogenic, and cardiovascular action of melanocortins. Endocrinology 2009, 150:5351-5361.

274. Skibicka KP, Grill HJ: Energetic responses are triggered by caudal brainstem melanocortin receptor stimulation and mediated by local sympathetic effector circuits. Endocrinology 2008, 149:3605-3616.

275. Zheng H, Corkern M, Stoyanova I, Patterson LM, Tian R, Berthoud HR: Peptides that regulate food intake: appetite-inducing accumbens manipulation activates hypothalamic orexin neurons and inhibits POMC neurons. Am J Physiol 2003, 284:R1436-R1444.

276. Zheng H, Patterson LM, Phifer CB, Berthoud HR: Brain stem melanocortinergic modulation of meal size and identification of hypothalamic POMC projections. Am J Physiol 2005, 289:R247-R258.

277. Zheng H, Patterson LM, Rhodes CJ, Louis GW, Skibicka KP, Grill HJ, Myers MG Jr, Berthoud HR: A potential role for hypothalamomedullary POMC projections in leptin-induced suppression of food intake. Am J Physiol 2010, 298:R720-R728.

278. Berthoud HR: A new role for leptin as a direct satiety signal from the stomach. Am J Physiol Regul Integr Comp Physiol 2005, 288:R796-R797.

279. Berthoud HR, Sutton GM, Townsend RL, Patterson LM, Zheng H: Brainstem mechanisms integrating gut-derived satiety signals and descending forebrain information in the control of meal size. Physiol Behav 2006, 89:517-524

280. Bach FW, Yaksh TL: Release of beta-endorphin immunoreactivity into ventriculo-cisternal perfusate by lumbar intrathecal capsaicin in the rat. Brain Res 1995, 701:192-200.

281. Bach FW, Chaplan SR, Jang J, Yaksh TL: Cerebrospinal fluid beta-endorphin in models of hyperalgesia in the rat. Regul Pept 1995, 59:79-86.

282. Strahlendorf JC, Strahlendorf HK, Barnes CD: Inhibition of periaqueductal gray neurons by the arcuate nucleus: partial mediation by an endorphin pathway. Exp Brain Res 1982, 46:462-466.

283. Skinner DC, Caraty A: Measurement and possible function of $\mathrm{GnRH}$ in cerebrospinal fluid in ewes. Reproduction 2002, 59:25-39.

284. Skinner DC, Caraty A, Malpaux B, Evans NP: Simultaneous measurement of gonadotropin-releasing hormone in the third ventricular cerebrospinal fluid and hypophyseal portal blood of the ewe. Endocrinology 1997, 138:4699-4704.

doi:10.1186/2045-8118-9-16

Cite this article as: Veening et al:: Volume transmission of beta-endorphin via the cerebrospinal fluid; a review. Fluids and Barriers of the CNS 2012 9:16. 